\title{
Proliferation and the Logic of the Nuclear Market
}

ceived as much attention from policymakers and security experts as nuclear proliferation. The United States, for example, has made nonproliferation a strand of its grand strategy since $1945 .{ }^{1}$ In the early Cold War period, many believed that nuclear weapons would become widespread. India's nuclear test in May 1974 appeared to buttress that assessment. ${ }^{2}$ Yet, only ten states have acquired nuclear weapons, and one of them (South Africa) gave them up. This article aims to explain why more countries have not acquired these weapons. My argument is that competition in the nuclear market is the key to understanding the conditions that facilitate or thwart the spread of nuclear weapons.

The logic of the nuclear market suggests that suppliers will compete to sell technologies and materials that could make it easier for states to develop nuclear weapons. The free market that emerged in the 1950s, characterized by intense competition among suppliers, seemed an especially dangerous pathway to proliferation by the 1970s. Not only did it play a key role in India's nuclear program, but it also appeared that other countries would follow suit. That

Eliza Gheorghe is Assistant Professor in the International Relations Department at Bilkent University. ORCID iD: https://orcid.org/0000-0003-0849-5397.

The author thanks Målfrid Braut-Hegghammer, Mariana Budjeryn, Andrew Coe, Alexandre Debs, Anne Deighton, Francis Gavin, Brendan Green, Kelly Greenhill, Mariya Grinberg, Eugenia Gusilov, Liviu Horovitz, Alexander Lanoszka, Robert Litwak, John Mearsheimer, Nicholas Miller, Owen Miller, Nuno Monteiro, Leopoldo Nuti, Joseph Pilat, Paul Poast, Or Rabinowitz, Judith Reppy, Scott Sagan, and the anonymous reviewers for their comments. She is also grateful to Mauro Elli, Alexandra Filipescu, Adriana Gheorghe, and Krzysztof Olszewski for their help with research. In addition, the author benefited from the insights provided by the participants in the Judith Reppy Institute for Peace and Conflict Studies weekly seminar at Cornell University; the Program on International Security Policy at the University of Chicago; the Project on Managing the Atom at the John F. Kennedy School of Government (Harvard Kennedy School); the Nuclear Age Conference at Yale University; the Peace Science Society Conference at Notre Dame; the Working Group on Conflict, Security, and Public Policy at the Harvard Kennedy School; the 2017 International Studies Association annual convention; and the 2018 annual meeting of the American Political Science Association. She acknowledges financial support from the University of Vienna, the Stanton Foundation, the Romanian Cultural Institute, and the Nuclear Proliferation International History Project at the Woodrow Wilson International Center for Scholars.

1. Francis J. Gavin, "Strategies of Inhibition: U.S. Grand Strategy, the Nuclear Revolution, and Nonproliferation," International Security, Vol. 40, No. 1 (Summer 2015), pp. 9-46, doi.org/10.1162/ ISEC_a_00205; and Or Rabinowitz and Nicholas L. Miller, "Keeping the Bombs in the Basement: U.S. Nonproliferation Policy toward Israel, South Africa, and Pakistan," International Security, Vol. 40, No. 1 (Summer 2015), pp. 47-86, doi.org/10.1162/ISEC_a_00207.

2. William Burr, "The Making of the Nuclear Suppliers Group, 1974-1976" (Washington, D.C.: Woodrow Wilson International Center for Scholars, 2014).

International Security, Vol. 43, No. 4 (Spring 2019), pp. 88-127, https://doi.org/10.1162/ISEC_a_00344 (c) 2019 by the President and Fellows of Harvard College and the Massachusetts Institute of Technology. 
route to the bomb, however, was blocked by the United States and the Soviet Union. The conditions for thwarting supplier competition may be eroding, however, potentially threatening an increase in the number of nuclear weapons states (NWS).

I base my analysis on a theory of proliferation that posits that the spread of nuclear weapons is largely a function of the interactions among suppliers, buyers, and thwarters in the nuclear market. In the absence of a supplier cartel that can regulate transfers of nuclear material and technology, more suppliers will enter the market and the level of the competition among them will increase, as they vie for market share. This facilitates the spread of nuclear material and technology, because buyers can play suppliers off against each other. The ensuing transfers help countries either acquire nuclear weapons or become hedgers - that is, states standing at the threshold of weaponization. The thwarters are the great powers; they seek to counter proliferation by limiting what suppliers can sell and by putting safeguards on potentially dangerous technologies that can be sold. Their success depends on two key structural factors: the global distribution of power and the intensity of their security rivalry. The thwarter's success at countering proliferation is most likely in unipolarity, least likely in multipolarity, and falls somewhere in between when the system is bipolar. Moreover, the more intense the rivalry among the great powers in bipolarity and multipolarity, the less effective thwarting will be, and thus the more likely it is that nuclear weapons will spread.

My theory predicts that more countries would acquire nuclear weapons during the early Cold War (1945-74) than either the late Cold War (1975-90) or the post-Cold War period (1991-2014). ${ }^{3}$ Following World War II, the superpowers were locked in a bitter security rivalry and thus were largely incapable of cooperating to thwart proliferation. They would be better situated to counter proliferation after their relations improved in the late Cold War. And once the United States became the sole pole in 1991, it would be well positioned to prevent countries from acquiring nuclear weapons. As the world is now moving into multipolarity, my theory predicts that the great powers will have difficulty cooperating to regulate the market, thus leading to an increase in proliferation.

Seven states acquired nuclear weapons in the early Cold War, which prompted fears of unbounded proliferation. Only two states, however, built a bomb in the late Cold War, while in the post-Cold War period, one country acquired nuclear weapons and one gave them up, for a net gain of zero.

3. My study ends in 2014 because the international system was then beginning to move from unipolarity to multipolarity. 
This article recognizes that two factors must be present for a state to become a proliferator. First, it must want to become a nuclear hedger or acquire nuclear weapons. Second, it must have the materials and technology, as well as the engineering and scientific expertise, necessary for building nuclear weapons. This article does not examine why countries want to become proliferators. It assumes that security is the main motive, although there are other motives as well. ${ }^{4}$ Instead, it seeks to analyze how countries, once they have decided to become hedgers or acquire the bomb, use the nuclear market to achieve their goal. ${ }^{5}$

The remainder of this article is organized into six sections. In the first section, I discuss six pathways to proliferation and define key terms. In the second and third sections, I present my theory and research design. In the fourth section, I analyze the broad patterns of proliferation from 1945 to 2014 to determine how well they fit with my theory. I also examine how the behavior of the thwarters - the United States and the Soviet Union-affected the evolution of the nuclear market and the nuclear pursuits of India, South Korea, and Romania. The fifth section considers the future of proliferation as the international system moves from unipolarity to multipolarity. In the conclusion, I offer policy recommendations and suggestions for future avenues of research.

\section{Pathways to the Bomb}

Six pathways are available to a state seeking to build a nuclear weapons capability. ${ }^{6}$ First, it can develop the necessary materials and technologies indigenously. ${ }^{7}$ Second, it can engage in multinational cooperation, whereby several

4. On the causes of proliferation, see Scott D. Sagan, "Why Do States Build Nuclear Weapons? Three Models in Search of a Bomb," International Security, Vol. 21, No. 3 (Winter 1996/97), pp. 5486, doi.org/10.2307/2539273; and Scott D. Sagan, "The Causes of Nuclear Weapons Proliferation," Annual Review of Political Science, Vol. 14, June 2011, pp. 225-244, doi.org/10.1146/annurev-polisci052209-131042.

5. I am not arguing that, once states acquire nuclear materials and technologies, they will reflexively develop an interest in building a nuclear arsenal. Many states secure the nuclear wherewithal for a peaceful program and show no interest in becoming a proliferator.

6. Countries that were "born" with the bomb following the break-up of a nuclear weapon state, such as Ukraine, Belarus, or Kazakhstan, fall outside the scope of this article. For a discussion of nuclear inheritance, see Mariana Budjeryn, "The Power of the NPT: International Norms and Ukraine's Nuclear Disarmament," Nonproliferation Review, Vol. 22, No. 2 (June 2015), pp. 203-237, doi.org/10.1080/10736700.2015.1119968.

7. For works on indigenous capabilities, see Dong-Joon Jo and Erik Gartzke, "Determinants of Nuclear Weapons Proliferation," Journal of Conflict Resolution, Vol. 51, No. 1 (February 2007), pp. 167-194, doi.org/10.1177/0022002706296158; R. Scott Kemp, “The Nonproliferation Emperor Has No Clothes: The Gas Centrifuge, Supply-Side Controls, and the Future of Nuclear Proliferation," International Security, Vol. 38, No. 4 (Spring 2014), pp. 39-78, doi.org/10.1162/ISEC_a_00159; Jacques E.C. Hymans, Achieving Nuclear Ambitions: Scientists, Politicians, and Proliferation (Cambridge: Cambridge University Press, 2012); Alexander H. Montgomery, "Stop Helping Me: When Nuclear Assistance Impedes Nuclear Programs," in Adam N. Stulberg and Matthew Fuhrmann, 
countries collaborate to develop a particular nuclear technology. ${ }^{8}$ Third, it can purchase these materials and technologies from another country in the nuclear market, commonly understood as nuclear trade..$^{9}$ Fourth, states may resort to smuggling rings. ${ }^{10}$ Fifth, a state might capture the nuclear facilities of a vanquished enemy. ${ }^{11}$ Sixth, international organizations created to aid countries in developing their civilian nuclear programs can inadvertently help those interested in proliferating by providing materials, technology, or both that can be used in a weapons program. ${ }^{12}$

All proliferators have used more than one pathway to acquire the bomb. In addition to developing indigenous capabilities, the United States, for instance, benefited from cooperation with Britain and Canada. The Soviet Union established an indigenous program with the help of German scientists and facilities captured at the end of World War II, spies involved in the United States' Manhattan Project, and centrifuge technology acquired from Sweden. Nevertheless, certain pathways matter more than others. Capturing an enemy's nuclear facilities has rarely happened, and while the International Atomic Energy Agency (IAEA) helps countries develop nuclear programs, it is also the world's nuclear watchdog. Illicit smuggling networks helped Pakistan and North Korea build nuclear weapons, but the black market is not nearly as robust as the licit one.

Indigenous means, multinational cooperation, and nuclear trade are the most common pathways to the bomb. Each offers advantages and disadvantages. Pursuit of an indigenous nuclear weapons capability protects the state against outside interference, but it is costly and does not guarantee the most efficient pathway to the bomb. Multinational cooperation allows collaborators to share knowledge, reduces the costs to each member, and boosts their abil-

eds., The Nuclear Renaissance and International Security (Stanford, Calif.: Stanford University Press, 2013), pp. 177-202; and Målfrid Braut-Hegghammer, Unclear Physics: Why Iraq and Libya Failed to Build Nuclear Weapons (Ithaca, N.Y.: Cornell University Press, 2016).

8. Margaret Gowing, "Britain, America, and the Bomb," in Michael L. Dockrill and John W. Young, eds., British Foreign Policy, 1945-1956 (London: Palgrave Macmillan, 1989), pp. 31-46; and Shane J. Maddock, Nuclear Apartheid: The Quest for American Atomic Supremacy from World War II to the Present (Chapel Hill: University of North Carolina Press, 2010), pp. 13-19.

9. Matthew Kroenig, Exporting the Bomb: Technology Transfer and the Spread of Nuclear Weapons (Ithaca, N.Y.: Cornell University Press, 2010); and Matthew Fuhrmann, Atomic Assistance: How "Atoms for Peace" Programs Cause Nuclear Insecurity (Ithaca, N.Y.: Cornell University Press, 2012). 10. Alexander H. Montgomery, "Ringing in Proliferation: How to Dismantle an Atomic Bomb Network," International Security, Vol. 30, No. 2 (Fall 2005), pp. 153-187, doi.org/10.1162/01622880 5775124543.

11. David Holloway, Stalin and the Bomb: The Soviet Union and Atomic Energy, 1939-1956 (New Haven, Conn.: Yale University Press, 1996), pp. 108-112, 178-180, 190.

12. Robert L. Brown and Jeffrey M. Kaplow, "Talking Peace, Making Weapons: IAEA Technical Cooperation and Nuclear Proliferation," in "Nuclear Posture, Nonproliferation Policy, and the Spread of Nuclear Weapons," special issue, Journal of Conflict Resolution, Vol. 58, No. 3 (April 2014), pp. 402-428, doi.org/10.1177/0022002713509052. 
ity to solve difficult problems. This tight interdependence, however, limits a proliferator's flexibility in its nuclear pursuits. A nuclear market populated by multiple suppliers competing for market share allows buyers to maximize the benefits they obtain regarding the quality of the product, price, and, most importantly for proliferation purposes, terms of use. ${ }^{13}$ In short, the nuclear market is a significant pathway to proliferation, which has contributed to varying degrees to the nuclear programs of a majority of the world's nuclear weapon states: China, France, India, Israel, North Korea, Pakistan, South Africa, and the Soviet Union. ${ }^{14}$

In a nuclear market, participants engage in commercial transactions involving technologies, materials, and know-how related to nuclear energy. The main protagonists in this market are buyers, suppliers, and thwarters. The nuclear market is unlike any other market, because the products being traded can be used to build nuclear weapons. The possibility that transfers might be used for military purposes is always on the minds of thwarters.

Among buyers, my focus is on countries that are determined to become proliferators. A proliferator can have two possible end goals: becoming a nuclear hedger or becoming a nuclear weapons state. ${ }^{15}$ An aspiring hedger seeks to develop a robust infrastructure comprising the full nuclear fuel cycle. Doing so allows it to keep open the option of becoming a nuclear weapons state on short notice, without having a dedicated nuclear weapons program. A hedger must have a pilot or industrial-scale enrichment and reprocessing (ENR) facility that can readily produce fissile material for a bomb.

An aspiring NWS either acquires the necessary materials and technology to

13. For a discussion of supplier competition, see Joseph S. Nye, "Maintaining a Nonproliferation Regime," International Organization, Vol. 35, No. 1 (Winter 1981), pp. 15-38, doi.org/10.1017/ S0020818300004069; Robert Boardman and James F. Keeley, eds., Nuclear Exports and World Politics: Policy and Regime (New York: St. Martin's, 1983); William Walker and Måns Lönnroth, Nuclear Power Struggles: Industrial Competition and Proliferation Control (London: George Allen \& Unwin, 1983); Benjamin N. Schiff, International Nuclear Technology Transfer: Dilemmas of Dissemination and Control (London: Croom Helm, 1984); Rodney W. Jones et al., eds., The Nuclear Suppliers and Nonproliferation: International Policy Choices (Washington, D.C.: Center for Strategic and International Studies, 1985); William C. Potter, ed., International Nuclear Trade and Nonproliferation: The Challenge of Emerging Suppliers (Lexington, Mass.: Lexington Books, 1990); J. Samuel Walker, "Nuclear Power and Nonproliferation: The Controversy over Nuclear Exports, 1974-1980," Diplomatic History, Vol. 25, No. 2 (Spring 2001), pp. 215-249, doi.org/10.1111/0145-2096.00260; and Sungyeol Choi and Il Soon Hwang, "Effects of Nuclear Technology Export Competition on Nuclear Nonproliferation," Nonproliferation Review, Vol. 22, No. 3-4 (September/December 2015), pp. 341-359, doi.org/ $10.1080 / 10736700.2016 .1154267$. None of these scholars, however, argue that the structure of the international system explains variation in the competitiveness of the market.

14. For a longer discussion of these negotiations, together with the primary sources on which this research relies, see the online appendix at doi.org/10.7910/DVN/70TJHT.

15. Ariel E. Levite, "Never Say Never Again: Nuclear Reversal Revisited," International Security, Vol. 27, No. 3 (Winter 2002/03), pp. 59-88, doi.org/10.1162/01622880260553633; and Vipin Narang, "Strategies of Nuclear Proliferation: How States Pursue the Bomb," International Security, Vol. 41, No. 3 (Winter 2016/17), p. 113, doi.org/10.1162/ISEC_a_00268. 
build a bomb or uses its existing nuclear capabilities to achieve that objective. A country remains an aspirant until it has either "exploded a nuclear weapon or other nuclear explosive device" or assembled a nuclear bomb. ${ }^{16}$ In the process, it may build nuclear reactors, laboratory-, pilot-, and industrial-scale ENR facilities, but only when a state puts all these ingredients together to produce a bomb or test a nuclear device does it transition from an aspirant to a nuclear weapons state.

Suppliers are the countries that export nuclear technologies, materials, and expertise that can be used for both civilian and military purposes. The key technologies that suppliers export, which are the building blocks of a nuclear program, include research reactors, power reactors, and, most importantly for proliferation purposes, ENR facilities. Suppliers also sell uranium and plutonium, the main materials for powering reactors and building nuclear weapons. Transfers involving expertise can take the form of training, educational exchanges, or formal schooling.

The great powers are the thwarters. ${ }^{17}$ They act as market regulators. Their aim is to prevent the sale of technologies such as ENR that facilitate proliferation. They can also put safeguards on transfers that proliferators might use to build the bomb. These measures are designed to inhibit, contain, and roll back proliferation. Inhibition is designed to prevent aspiring NWS and aspiring hedgers from reaching their goals. ${ }^{18}$ In effect, inhibition leads to containment, which involves keeping the number of hedgers and NWS constant. Rollback occurs when a state ceases being an aspiring NWS, an aspiring hedger, a hedger, or a nuclear weapons state altogether.

\section{A Theory of Nuclear Proliferation}

Before describing my theory, I explain why countries become hedgers or NWS. States pursue a hedging strategy or try to acquire nuclear weapons for different reasons, including security concerns, bureaucratic politics, or the quest for prestige. My theory assumes that security is the main motive, because possessing a nuclear arsenal is the optimal way for a country to guarantee its survival-the highest priority for all states in the international system.

I argue that states are most likely to become NWS or hedgers through the nuclear market. The more suppliers there are, the more competition there is

16. See Article 9 in United Nations Office for Disarmament Affairs, Treaty on the Non-Proliferation of Nuclear Weapons (New York: United Nations Office for Disarmament Affairs, July 1, 1968).

17. For the period of the Cold War, this article will use "great powers" and "superpowers" interchangeably. Minor powers cannot be thwarters, because they do not have the economic and military wherewithal to limit competition among suppliers.

18. Gavin, "Strategies of Inhibition." 
among them, and the easier it is for buyers to obtain nuclear transfers that could be used to develop and maintain a nuclear weapons program. The great powers, however, have strong incentives to regulate the market to curb proliferation. Whether they succeed depends largely on the distribution of power among them as well as the intensity of their security rivalry.

\section{A BUYER'S MARKET}

A market with multiple suppliers works to the buyer's advantage in three related ways. First, buyers have finite resources and cannot buy all the goods that all the sellers are offering. For every sale one vendor makes, several vendors will mark up a loss. Sellers understand that, in a competitive market, the probability of closing a deal decreases as the number of suppliers increases. The core motivation for nearly all vendors is to maximize market share, which tends to give their competition a zero-sum quality. ${ }^{19}$

Second, intense competition among multiple suppliers allows buyers to play them off against one another. A supplier in a competitive market fears that its rivals will steal a customer by offering a better deal. A buyer can exploit this situation by engaging them in a bidding war. The greater the number of suppliers, the fiercer their competition, and therefore, the easier it is for buyers to manipulate them. ${ }^{20}$

Buyers in a competitive market sometimes do not explicitly manipulate suppliers, but instead negotiate deals with a single supplier. Such one-on-one negotiations might seem fundamentally different from supplier manipulation, but they are not. ${ }^{21}$ Sellers in a competitive market are always under pressure from their rivals, whether buyers are openly pitting them against each other or not. All suppliers know that buyers invariably have other options. ${ }^{22}$ The shadow of supplier manipulation hovers over one-on-one negotiations, even if the buyer is not playing sellers off against each other.

19. This is not to deny that other considerations such as security, domestic politics, prestige, and especially profit can affect supplier behavior. See Kroenig, Exporting the Bomb; and Fuhrmann, Atomic Assistance. Market share, however, is a seller's primary goal, because it is the essential condition for pursuing other goals. For an explanation of why suppliers prize market share above profit, see Robert D. Buzzell, Bradley T. Gale, and Ralph G.M. Sultan, "Market Share-A Key to Profitability," Harvard Business Review, Vol. 53, No. 1 (January 1975), pp. 97-106; and Horace Dediu, "Which Size Really Matters? Market Share vs. Profit Share," Asymco blog, October 18, 2010, http:// www.asymco.com/2010/10/18/what-really-matters-market-share-vs-profit-share/.

20. The mathematical formula that illustrates this phenomenon is $C(n, r)=\frac{n !}{r !(n-r) !}$. A buyer that has access to ten suppliers and chooses to pit four of them against each other at a time ends up with 210 possible bids.

21. The only situation where buyers cannot employ supplier manipulation is when there is a single seller, which has hardly ever been the case in the nuclear market.

22. George J. Stigler, "A Theory of Oligopoly," Journal of Political Economy, Vol. 72, No. 1 (February 1964), p. 47, doi.org/10.1086/258853. 
Third, a competitive market allows buyers to obtain better prices, products, and terms of use-all of which facilitate proliferation. Suppliers will want to make their offers to potential buyers as attractive as possible by lowering the costs of nuclear materials and technology. ${ }^{23}$ The less money a buyer has to spend on procuring these items, the more money it has to put toward a military program.

Suppliers may also seek to improve their chances by offering better products, some of which could increase the likelihood of proliferation. For example, increasing a reactor's capacity produces not only more electricity, but also larger quantities of spent fuel, from which plutonium can be extracted.

Finally, supplier competition facilitates proliferation by relaxing the conditions for nuclear transfers. Under market pressure, suppliers vie with each other to offer the most malleable rules for using their products. A supplier known for enforcing nonproliferation norms and practices risks losing contracts to rival vendors less concerned about preventing proliferation. Turning a blind eye to the potential diversion of nuclear technology for military use can make or break a deal.

\section{THE ROLE OF THE THWARTER}

Thwarters (i.e., the great powers) seek to curb proliferation by preventing buyers from exploiting the competition among suppliers. They create cartels that force vendors to comply with a fixed set of rules. ${ }^{24}$ These protocols determine what buyers can sell and under what conditions in two ways. First, they prohibit members from selling certain products, save for special circumstances. In practice, this means pressuring suppliers to refrain from selling ENR technology, although exceptions may be made for buyers that already have ENR. If vendors cannot sell ENR, they will no longer compete to sell that product, which helps curb proliferation.

Second, cartels can impose comprehensive safeguards designed to keep track of fissile materials used in nuclear installations and to verify whether those installations are serving peaceful purposes. ${ }^{25}$ The ideal instrument in this regard is what is known as "full-scope safeguards," which apply not only to the technologies that buyers acquire from suppliers, but to all of their nuclear

23. Joseph E. Stiglitz, "Competition and the Number of Firms in a Market: Are Duopolies More Competitive than Atomistic Markets?" Journal of Political Economy, Vol. 95, No. 5 (October 1987), pp. 1041-1061, doi.org/10.1086/261501.

24. David Fischer, "The London Club and the Zangger Committee: How Effective?" in Kathleen Bailey and Robert Rudney, eds., Proliferation and Export Controls (Lanham, Md.: University Press of America, 1993), p. 40.

25. Laura Rockwood, "How the IAEA Verifies If a Country's Nuclear Program Is Peaceful or Not: The Legal Basis," in "The Verification of Arms Control Agreements," special issue, Bulletin of the Atomic Scientists, Vol. 74, No. 5 (September 2018), p. 319, doi.org/10.1080/00963402.2018.1507789. 
facilities as well. Therefore, full-scope safeguards prevent buyers from using either imported or indigenous technologies to pursue a nuclear weapons program. Cartels can apply comprehensive safeguards to two categories of nuclear technology: ENR and reactors, which include both research reactors and nuclear power plants. Although thwarters seek to abolish the ENR market, there may be special circumstances where that technology is sold to selected buyers. In such cases, the cartel mandates that comprehensive safeguards accompany the sale. The cartel does not prohibit reactor sales, however, because without ENR, a state cannot produce the fissile material necessary for building nuclear weapons.

A cartel's key operating principle is that its members act in unison. ${ }^{26}$ Each member incorporates the same guidelines into its nuclear export policies, so that they are all in sync. When suppliers coordinate with each other and form a united front, buyers cannot manipulate them. The guidelines, in effect, institute self-censorship.

Cartels also operate as decisionmaking forums. To achieve coordination, cartel members resort to consultations and information sharing. Unanimity is key. If even one cartel member opposes a transfer, or if a waiver for an exception is not granted, the transfer does not take place.

Cartels change the market in ways that reduce the likelihood of proliferation but do not necessarily prevent states from aspiring to become NWS or hedgers. Countries possessing only reactors will find it difficult to become a hedger or a nuclear weapons state, however, because they cannot rely on supplier manipulation to secure ENR. States with ENR can secure additional ENR facilities, but they would have to accept comprehensive safeguards designed to prevent them from using any of their nuclear facilities for military purposes. Countries without nuclear facilities can manipulate suppliers to secure reactors, and if they seek to weaponize, they would become aspiring NWS or aspiring hedgers. An effective cartel, however, would make it almost impossible for them to become actual hedgers or NWS.

Such cartels can therefore also reduce the number of suppliers in the market; not all suppliers, however, join cartels, given the considerable economic benefits that they can accrue in the market. They are thus freer than cartel members to set terms that satisfy buyers.

Cartels are not the only tools great powers employ to stem proliferation. Thwarters can also threaten to sanction proliferators, destroy their nuclear facilities, or abandon allies seeking to become nuclear weapons states. $^{27}$

26. Mancur Olson, The Logic of Collective Action: Public Goods and the Theory of Groups (Cambridge, Mass.: Harvard University Press, 2002), p. 96.

27. Nicholas L. Miller, "The Secret Success of Nonproliferation Sanctions," International Organiza- 
These strategies are likely to fail, however, if proliferators can acquire nuclear technology-especially ENR - on the nuclear market. For example, a determined proliferator facing sanctions can still buy ENR from a willing supplier. Wrecking a proliferator's nuclear facilities matters little if the target state can buy the technology it needs to start over and then locate it in places largely immune from attack. Threatening to forsake an ally, which would seem foolish for strategic reasons, is unlikely to succeed if allies can acquire the ultimate deterrent from eager suppliers. The limits of these alternative strategies underscore that cartels offer the best means to maximize the prospects of thwarting proliferation.

Despite powerful incentives, thwarters cannot always curb nuclear trade. For example, creating a cartel may not be possible. Instead, thwarters may try to influence the market by selling nuclear materials and technologies themselves. In so doing, they shape which technologies are transferred and how they are used. ${ }^{28}$ This also puts them in a better position to assess a buyer's ultimate intentions. Thwarters will export nuclear technologies to as many countries as possible with the ultimate aim of monopolizing all nuclear trade. ${ }^{29}$

Two factors largely determine when great powers are best able to create an effective cartel: the number of great powers in the world and the intensity of their rivalry. Building and maintaining an effective export control system requires significant cooperation and coordination among the thwarters. Yet, security rivalries complicate these tasks. Great power rivalry takes one of two forms. Intense security competition impedes the formation and management of cartels, because the thwarters have powerful incentives to undermine each other, thus making coordination difficult. Great powers engaged in mild security rivalry have less difficulty synchronizing their export control policies. In short, the more intense the security rivalry among the great powers, the less likely it is they will form an effective cartel, which increases the probability of proliferation.

tion, Vol. 68, No. 4 (Fall 2014), pp. 913-944, doi.org/10.1017/S0020818314000216; Sarah E. Kreps and Matthew Fuhrmann, "Attacking the Atom: Does Bombing Nuclear Facilities Affect Proliferation?" Journal of Strategic Studies, Vol. 34, No. 2 (April 2011), pp. 161-187, doi.org/10.1080/ 01402390.2011.559021; Muhammet A. Bas and Andrew J. Coe, "A Dynamic Theory of Nuclear Proliferation and Preventive War," International Organization, Vol. 70, No. 4 (Fall 2016), pp. 655-685, doi.org/10.1017/S0020818316000230; Alexandre Debs and Nuno P. Monteiro, Nuclear Politics: The Strategic Causes of Proliferation (Cambridge: Cambridge University Press, 2016); and Nicholas L. Miller, "Nuclear Dominoes: A Self-Defeating Prophecy?" Security Studies, Vol. 23, No. 1 (2014), pp. 33-73, doi.org/10.1080/09636412.2014.874189.

28. Providing nuclear assistance to discourage states from pursuing a nuclear weapons capability was the main rationale behind Atoms for Peace and the Peaceful Atom. Peter R. Lavoy, "The Enduring Effects of Atoms for Peace," Arms Control Today, Vol. 33, No. 10 (December 2003), pp. 26-30, https://www.jstor.org/stable/23627140. See also Gavin, "Strategies of Inhibition," pp. 33-34.

29. Olson, The Logic of Collective Action, p. 37. 
Unipolarity is the optimal distribution of power for preventing and rolling back proliferation. The unipole is well positioned in the market to regulate supplier behavior because, by definition, no possibility of rivalry between great powers exists. This absence of rivalry eliminates the need for the sole pole to coordinate with other great powers. Furthermore, the unipole's unrivaled power facilitates its use of economic, diplomatic, and military might to influence suppliers' behavior. The unipole thus has abundant coercive leverage it can apply to convince other cartel members to cooperate with it and benefit from its policies. ${ }^{30}$ Therefore, the unipole is well situated to impose its terms on suppliers, including those outside the cartel.

Leaving aside great power security rivalries, counterproliferation is more difficult in multipolarity than it is in bipolarity, for two reasons. First, coordination among the great powers becomes increasingly difficult as their number rises. Conflicting interests and incentives to free ride and pass the buck will tend to emerge, and solutions may prove elusive. ${ }^{31}$ For instance, because cartels operate on the principle of unanimity, a thwarter can potentially block a worthwhile proposal if it fears that the proposal might compromise its security. Dealing with rule breakers is also likely to be problematic, because thwarters must first agree on the terms of punishment. If wrongdoers believe that agreement is unlikely, they can avoid punishment, which could lead to an increase in rule breaking, which in turn would undermine the cartel.

Second, in bipolarity, states are organized into two rival camps with stable alliances. ${ }^{32}$ Consequently, the great powers are better positioned than they are in multipolarity to monitor suppliers in their orbit and apply pressure to keep them from selling sensitive nuclear technologies. Still, if the rival great powers are engaged in intense security competition, cooperation is likely to prove difficult. They may even have reasons to undermine each other's counterproliferation policies.

Five predictions can be derived from the discussion above. First, in multipolar systems where the great powers intensely compete for security, market regulation is very weak, which leads to a sharp uptick in proliferation. Second, the combination of bipolarity and intense security rivalry among the great powers leads to weak regulation of the market, which results in a steep growth in proliferation. Third, in multipolar systems where the security rivalry among the great powers is mild, the regulation of the market is limited, thus bringing about a moderate rise in proliferation. Fourth, in bipolar systems where the se-

30. Nuno P. Monteiro, Theory of Unipolar Politics (New York: Cambridge University Press, 2014), pp. $153-154$.

31. Olson, The Logic of Collective Action, pp. 33-35.

32. Kenneth N. Waltz, Theory of International Politics (Reading, Mass.: Addison-Wesley, 1979), p. 163. 


\begin{tabular}{|c|c|c|}
\hline $\begin{array}{l}\text { Variation in Polarity and Intensity of } \\
\text { Security Rivalry }\end{array}$ & $\begin{array}{l}\text { Level of Regulation by } \\
\text { the Cartel }\end{array}$ & $\begin{array}{l}\text { Level of } \\
\text { Proliferation }\end{array}$ \\
\hline multipolarity and intense security rivalry & very weak regulation & $\begin{array}{l}\text { sharp uptick in } \\
\text { proliferation }\end{array}$ \\
\hline bipolarity and intense security rivalry & weak regulation & $\begin{array}{l}\text { steep growth in } \\
\text { proliferation }\end{array}$ \\
\hline multipolarity and mild security rivalry & limited regulation & $\begin{array}{l}\text { moderate rise in } \\
\text { proliferation }\end{array}$ \\
\hline bipolarity and mild security rivalry & strong regulation & $\begin{array}{l}\text { slowdown in } \\
\text { proliferation }\end{array}$ \\
\hline unipolarity (no security rivalry) & very strong regulation & $\begin{array}{l}\text { plateauing } \\
\text { proliferation }\end{array}$ \\
\hline
\end{tabular}

curity rivalry is mild, market regulation is strong, and proliferation slows down. Fifth, market regulation is very strong in unipolarity, and proliferation plateaus (see table 1).

\section{Research Design}

To test my theory that competition in the market largely accounts for why the number of nuclear weapons states since 1974 has remained small, I compiled a comprehensive chronology of nuclear trade. I thus identified the suppliers and recipients of nuclear materials and technologies from 1939 to 2014. My theory focuses on state-to-state nuclear transfers, which include technology, materials, and know-how.

I count exporting countries as suppliers, not nonstate actors or individual companies (private or state owned) operating within their national borders. Firms must secure governmental approval before exporting nuclear technology, which allows for treating states as unitary actors. To calculate the number of suppliers, I used sources in eight languages (English, French, German, Italian, Portuguese, Romanian, Russian, and Spanish), including primary documents from twenty archives, and dozens of interviews, to identify the providers of each research reactor, nuclear power plant, and ENR facility in the world (774 research reactors, 671 power reactors, and 254 ENR plants). ${ }^{33}$ The nuclear market includes two kinds of suppliers. Actual suppliers are countries that have sold nuclear technology to a buyer, whereas potential suppliers possess that technology, but have not yet exported it. In depicting the broad patterns of proliferation, I look only at actual suppliers. Doing so provides a more conser-

33. For a list of suppliers and a discussion of my coding decisions, see the online appendix. 
vative estimate of supplier competition and avoids including countries that might have had no interest in becoming exporters. In the case studies, however, I also examine buyers' negotiations with potential suppliers, given their clear intention to sell.

The nature of the competition among suppliers is ultimately shaped by systemic factors - the polarity of the system and the intensity of the security rivalry among the great powers. Thus, the nuclear age must be divided into different periods based on the shape of great power politics in each one. Regarding proliferation, I build on the work of Phillip Bleek, Matthew Fuhrmann and Benjamin Tkach, and Vipin Narang to identify and count the number of countries in pursuit of the military applications of the atom and the duration of their programs (see figure 1). ${ }^{34}$

I employ two methods to determine whether my theory helps explain why the number of NWS did not significantly increase after 1974. First, I analyze the broad patterns, wherein I present five curves that depict the number of (1) NWS, (2) aspiring NWS, aspiring hedgers, and hedgers, (3) actual ENR suppliers, (4) actual reactor suppliers, and (5) nuclear transfers. ${ }^{35}$ On each of these curves, I overlay the four periods of proliferation that reflect the key systemic changes that took place from 1939 to 2014. The first four curves appear in figure 2; the nuclear transfers curve appears in figure $3 .^{36}$

I focus my analysis on the period from 1945 to 2014, because there was no nuclear market during World War II, when states were just starting to pursue the bomb. My goals are threefold: (1) to determine whether changes over time in the market regarding the number of suppliers-especially ENR supplierscorrespond with what my theory predicts about the spread of NWS; (2) to assess whether those changes in the market match the trajectory of nuclear transfers; and (3) to gauge whether the changes involving supplier competition

34. Phillip C. Bleek, “When Did (and Didn't) States Proliferate? Chronicling the Spread of Nuclear Weapons" (Cambridge, Mass.: Project on Managing the Atom, Belfer Center for Science and International Affairs, John F. Kennedy School of Government, Harvard University, and James Martin Center for Nonproliferation Studies, Middlebury Institute of International Studies, Monterey, Calif.: June 2017); Matthew Fuhrmann and Benjamin Tkach, "Almost Nuclear: Introducing the Nuclear Latency Dataset," Conflict Management and Peace Science, Vol. 32, No. 4 (September 2015), pp. 443-461, doi.org/10.1177/0738894214559672; and Narang, "Strategies of Nuclear Proliferation."

35. In this analysis, I look exclusively at transfers of nuclear technology, and not materials and know-how. I focus on the sale of entire facilities, not the trade in component parts.

36. I use LOWESS fitted curves to describe the relationship between market competition and proliferation. LOWESS is a nonparametric estimation strategy that relaxes the assumption of linearity in the data. LOWESS fitted curves connect smoothed values obtained through weighted linear least squares regressions. William G. Jacoby, "LOESS: A Nonparametric, Graphical Tool for Depicting Relationships between Variables," Electoral Studies, Vol. 19, No. 4 (December 2000), pp. 577-613, doi.org/10.1016/S0261-3794(99)00028-1. Nuclear technology transfers are represented in a separate graph (figure 3 ) because of the different scale on which they are measured. New facilities per year compared to number of countries are shown in figure 2. 
Figure 1. The Nuclear Proliferation Timeline, 1939-2014

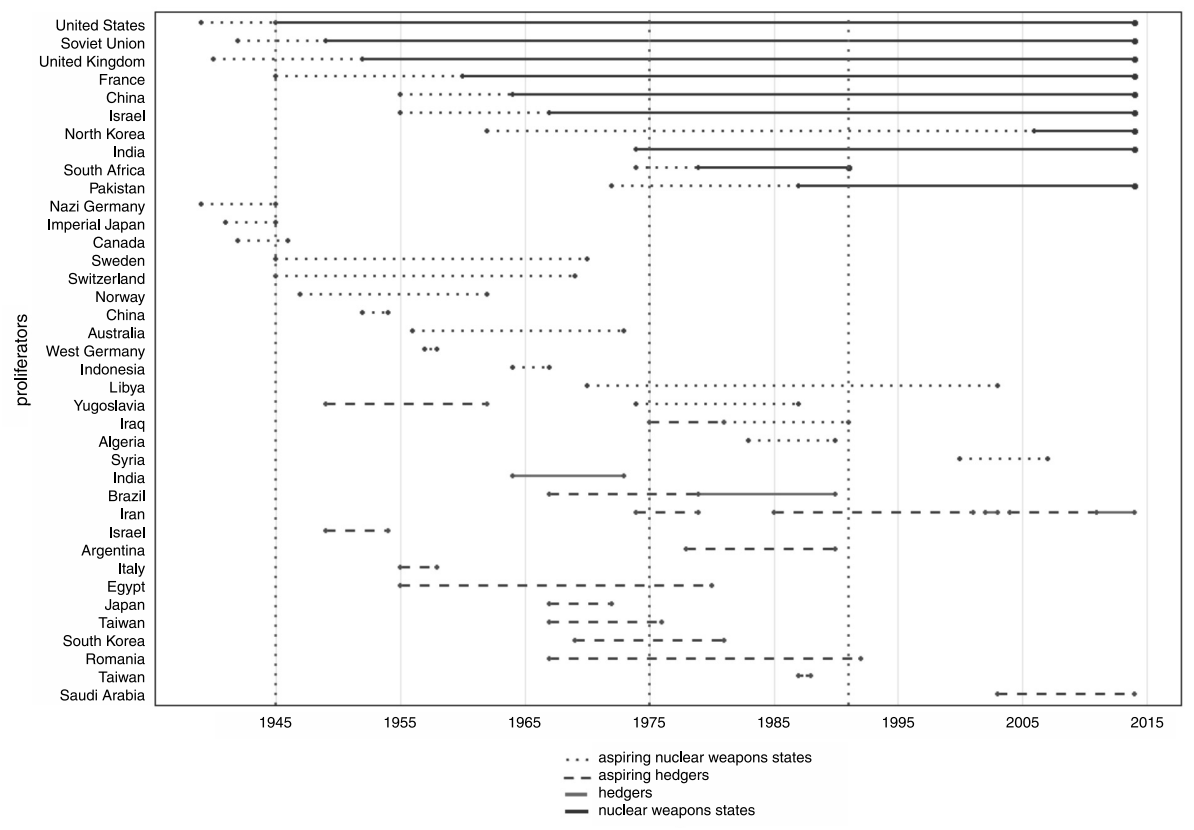

parallel the systemic shifts emphasized in my theory. Although this article focuses on NWS, figure 2 includes a curve for aspiring NWS, aspiring hedgers, and hedgers, because they represent the pool of candidates for the nuclear weapons club.

Second, I test my theory by performing an in-depth analysis of three proliferators: India, South Korea, and Romania. Each case is preceded by a brief discussion of thwarter behavior that is relevant for understanding the context in which those countries operated. My initial test sketches the broad trends involving proliferators, suppliers, and thwarters, but it says little about the causal processes that underpin the relationship among these actors. These cases, coupled with my discussion of thwarter interactions, seek to fill this void. ${ }^{37}$

I chose these cases for two reasons. First, a huge number of declassified documents have recently become available, which makes it possible to trace the efforts of India, South Korea, and Romania to acquire nuclear technologies from a wide range of suppliers and to examine the thwarters' effectiveness in deal-

37. In the cases, in addition to the trade in nuclear technology, I look at the market for nuclear materials and know-how. 
Figure 2. The Broad Patterns in the Data on Proliferation and the Nuclear Market

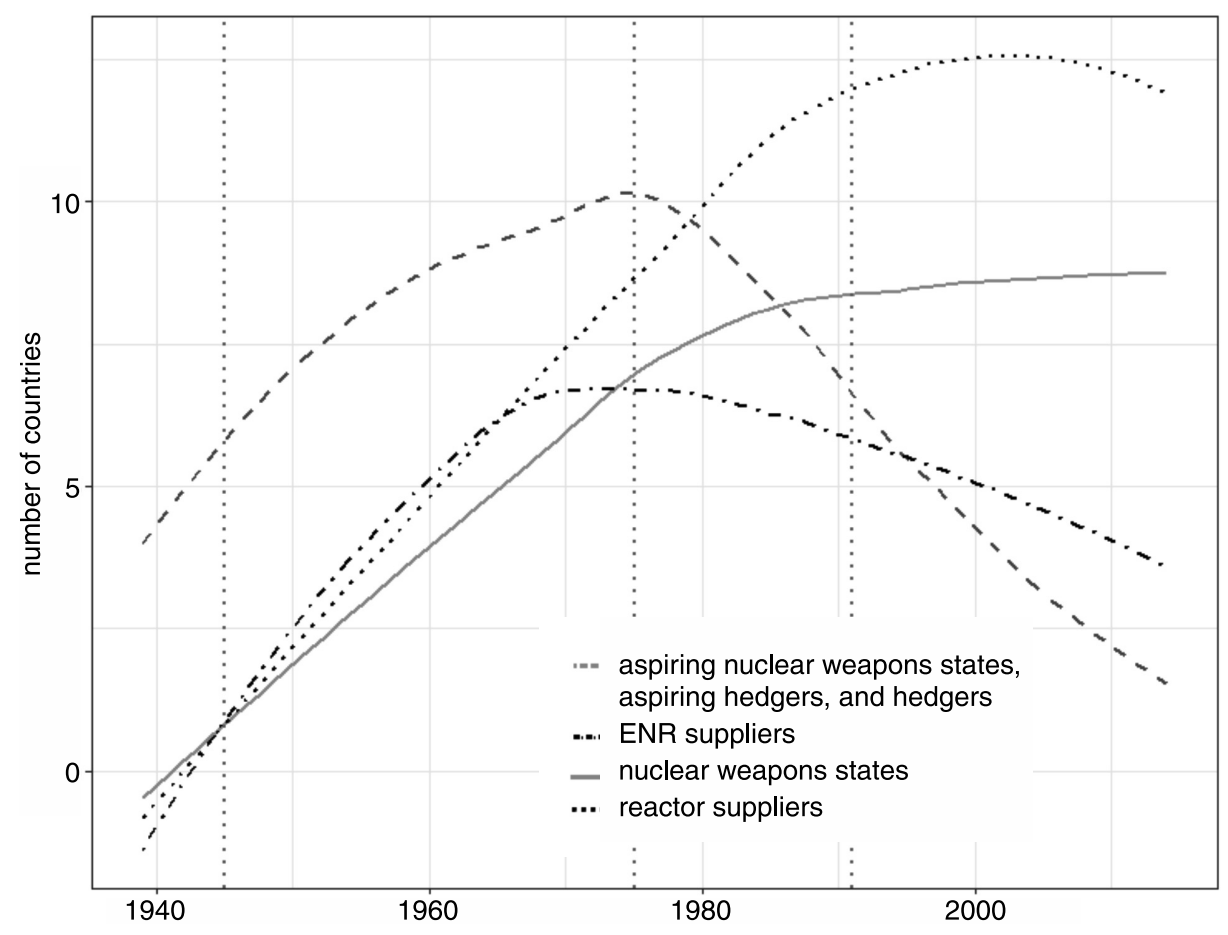

ing with them. Second, the three states experienced different levels of success in their nuclear pursuits, which allows me to examine whether that variation corresponds to changes in the nuclear market. ${ }^{38}$

\section{The History of Proliferation}

This section analyzes the broad patterns of proliferation, followed by the three case studies. The discussion of each country's nuclear pursuits is preceded by short sections that provide background on the different periods of proliferation.

38. The varied experiences of these three countries allows for a "most-different case" research design. John Gerring, "Case Selection for Case-Study Analysis: Qualitative and Quantitative Techniques," in Janet M. Box-Steffensmeier, Henry E. Brady, and David Collier, The Oxford Handbook of Political Methodology (Oxford: Oxford University Press, 2008). 
Figure 3. Evolution of Nuclear Trade, 1945-2014

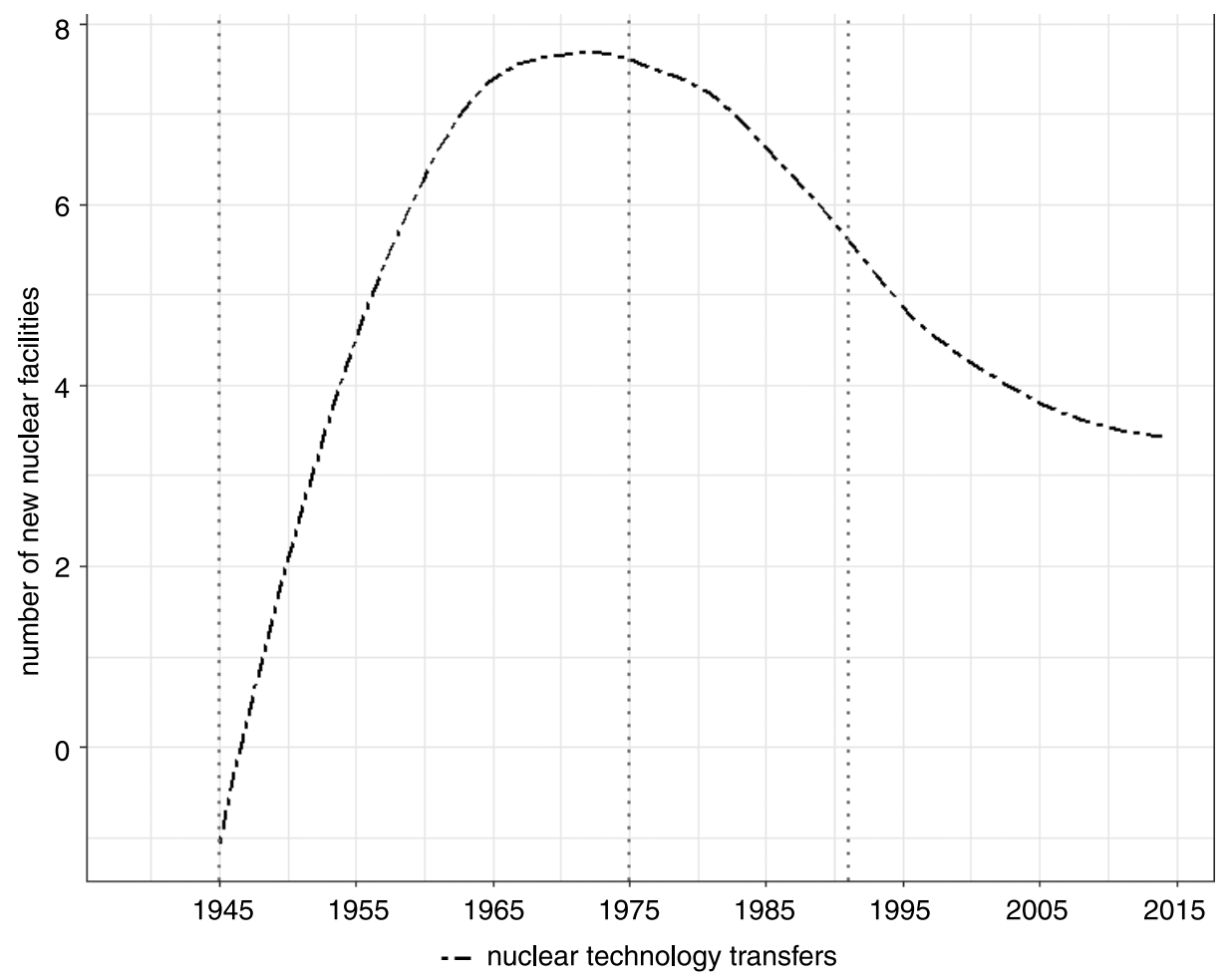

THE BROAD PATTERNS

The broad patterns of proliferation reflect the inflection points in great power politics. The Cold War was bipolar from start to finish, but the security rivalry between the United States and the Soviet Union was much more intense from 1945 to 1974 than it was from 1975 to 1990, a period that some scholars characterize as the "long détente." ${ }^{39}$ The system was unipolar in the post-Cold War period (1991-2014).

According to my theory, proliferation should have increased markedly in the early Cold War, slowed down in the late Cold War, and plateaued after

39. Jussi Hanhimäki, "Détente in Europe, 1962-1975," in Odd Arne Westad and Melvyn P. Leffler, eds., The Cambridge History of the Cold War, Vol. 2: Crises and Détente (Cambridge: Cambridge University Press, 2010), pp. 198-218. On the new periodization of the Cold War into two phases (the short Cold War and the "long détente"), see Gottfried Niedhart, "East-West Conflict: Short Cold War and Long Détente: An Essay on Terminology and Periodization," in Oliver Bange and Poul Villaume, eds., The Long Détente: Changing Concepts of Security and Cooperation in Europe, 1950s1980s (Budapest: Central European University Press, 2017), pp. 19-30. 
the Cold War. The empirical record seems to confirm these predictions (see figures 2 and 3). Of the ten NWS that emerged from 1945 to 2014, seven appeared from 1945 to 1974. From 1975 to 1990, only two emerged. From 1991 to 2014, the number of NWS leveled off, with the one new addition (North Korea) being canceled out by South Africa's decision to denuclearize.

As my theory predicts, the lack of cooperation between the great powers during the early Cold War fostered a steady growth in the number of suppliers and acute competition among them (see figure 2). ENR sales during this period were largely unrestricted. The thwarters' inability to create an effective suppliers' cartel from 1945 to 1974 helps explains why seven of the ten NWS emerged during this period.

During the late Cold War, there was a marked increase in cooperation among the thwarters, which slowed the growth in the number of NWS. In 1975, the United States and the Soviet Union started working together to create the Nuclear Suppliers Group (NSG), a highly effective suppliers' cartel that restricted the sale of ENR technology and also tightened the terms for reactor sales. Buyers therefore had few suppliers they could turn to for ENR transfers (see figure 3). ${ }^{40}$ This plummeting ENR market corresponds with the slowdown in the growth of NWS - there were just two during this period-as my theory would predict. With the coming of unipolarity in 1991, the United States was able to further strengthen the NSG. The number of proliferators at the start and end of the post-Cold War period is the same: nine.

In accordance with my theory, the aggregate number of new nuclear transfers per year (reactors and ENR) varies. Absent a suppliers' cartel in the early Cold War, sellers transferred significant quantities of nuclear technology, including ENR. With the creation of the NSG in the late Cold War, nuclear trade slowed. In the post-Cold War period, few new nuclear transfers occurred (see figure 3). Sales after 1975, and especially since 1990, were largely reactor transfers under safeguards. The few ENR transfers that have occurred since the NSG was created were also accompanied with strict safeguards.

Finally, the evolution of states aspiring to become hedgers or NWS, not to mention actual hedgers also sheds light on how changes in the market affect proliferation. By 2014, there had been twenty-four aspiring NWS, aspiring hedgers, and hedgers in the international system. As figure 2 shows, their numbers grew markedly in the early Cold War and then began to slow at the start of the late Cold War. Soon thereafter, their numbers started to decline, a trend that continued throughout the post-Cold War period. Figure 2 reflects

40. Gregory L. Schulte, “Stopping Proliferation before It Starts: How to Prevent the Next Nuclear Wave," Foreign Affairs, Vol. 89, No. 4 (July/August 2010), p. 91, https://www.jstor.org/stable/ 25680982. 
the tremendous concern attending India's 1974 nuclear test, as there were twelve aspiring NWS, aspiring hedgers, and hedgers from 1975 to 1980. Many of these countries probably would have become NWS or hedgers, save for the creation of the NSG. By 2014, Saudi Arabia was the only aspiring hedger in the system. If the nuclear market remains tightly regulated, especially regarding ENR, this sole aspirant will find it difficult to procure the necessary technology to become either a hedger or a nuclear weapons state. But if the NSG collapses, that aspirant will have a greater chance of buying the wherewithal to achieve its goals.

THE THWARTERS AND THE CREATION OF THE MARKET

Both the United States and the Soviet Union entered the nuclear age as thwarters. Leaders in Washington thought that the United States should be the only country to possess nuclear weapons. To this end, they restricted collaboration with their wartime partners-Britain and Canada-and adopted "strict unilateral nonproliferation measures" such as the Atomic Energy Act of $1946 .{ }^{41}$ Moscow also discouraged nuclear development among its Eastern European satellites and sought to keep nuclear weapons from other countries as well. ${ }^{42}$

Besides the superpowers, there was a select group of countries in the early days of the Cold War that possessed enough expertise and materials to build their own research reactors, nuclear power plants, and ENR facilities. They included Britain, Canada, France, Norway, and Sweden. They did not, however, share the superpowers' determination to inhibit the spread of nuclear weapons, believing that the thwarters would deal with this problem. Indeed, they had few qualms about selling nuclear wherewithal to interested buyers, despite opposition from Moscow and Washington. ${ }^{43}$ These countries helped create a nuclear market in the early 1950s.

Concerned that nuclear trade would spur proliferation and dissatisfied with the results of their efforts to prevent proliferation unilaterally, Washington and Moscow decided to supply nuclear technology themselves to shape the market. In December 1953, President Dwight Eisenhower announced the Atoms for Peace program, which offered states nuclear assistance in exchange for for-

41. Maddock, Nuclear Apartheid, p. 68.

42. Holloway, Stalin and the Bomb, pp. 157-158; and George A. Modelski, Atomic Energy in the Communist Bloc (London: Cambridge University Press, 1959), p. 124.

43. Nevile Butler, Atomic Energy: The International Background, Foreign Office Memorandum No. 193, September 11, 1945, PREM 8/117, Documents on British Policy Overseas, Series 1, Vol. 2 (London: H.M. Stationery Office, 1985); and Robert W. Bean, Airgram (1270) from the U.S. Embassy in Stockholm to the Department of State, June 25, 1951, 458.118/8-2552, box 2059, Central Decimal Files, Record Group 59, U.S. National Archives and Records Administration, College Park, Maryland (henceforth NARA). 
feiting the bomb. Shortly thereafter, Moscow launched a similar program, called the Peaceful Atom. ${ }^{44}$

In 1946, U.S. and Soviet leaders attempted to create a monopoly, under the aegis of the United Nations, that would regulate nuclear trade and keep proliferation in check. When that effort failed, the superpowers established the International Atomic Energy Agency in $1957 .{ }^{45}$ That institution relied on a system of safeguards to prevent the diversion of nuclear transfers to military purposes and ensure the peaceful use of nuclear energy. ${ }^{46}$ The IAEA had little authority, however, as not all members agreed to open their nuclear facilities to international scrutiny. Moscow and its East European allies, for example, refused to do so on the grounds that Western powers might use the information the IAEA gathered to their advantage. Both the failure to establish a monopoly and the shortcomings of the IAEA resulted largely from structural factors, which affected the market and thus shaped the proliferation landscape. Specifically, the bipolar distribution of power, coupled with intense superpower rivalry, hindered the United States and the Soviet Union from working together. Against this backdrop, suppliers were able to compete fiercely for market share, with few restrictions on what they sold.

\section{INDIA: MARKET MANIPULATION IN THE EARLY COLD WAR}

India became a hedger in 1964 and conducted a nuclear test in $1974 .{ }^{47}$ Given the intense rivalry between the superpowers and the absence of a cartel, the theory predicts that New Delhi should have been able to secure nuclear technology by playing suppliers off against each other. Equipped with these transfers, India should have been more likely to acquire nuclear weap-

44. As their names suggest, Atoms for Peace and Peaceful Atom were conceived as programs aimed at nonproliferation. Mara Drogan, "The Nuclear Imperative: Atoms for Peace and the Development of U.S. Policy on Exporting Nuclear Power, 1953-1955," Diplomatic History, Vol. 40, No. 5 (November 2016), pp. 949-950, doi.org/10.1093/dh/dhv049; Holloway, Stalin and the Bomb, pp. 348-349, 351, 354; and Roland Timerbaev, Rossiya i iadernoe nerasprostranenie: 1945-1968 (Russia and nuclear nonproliferation: 1945-1968) (Moscow: Nauka, 1999), pp. 81-84.

45. Elisabeth Roehrlich, "Negotiating Verification: International Diplomacy and the Evolution of Nuclear Safeguards, 1945-1972," Diplomacy and Statecraft, Vol. 29, No. 1 (2018), pp. 29-50, doi.org/ 10.1080/09592296.2017.1420520.

46. Elisabeth Roehrlich, "The Cold War, the Developing World, and the Creation of the International Atomic Energy Agency (IAEA), 1953-1957," Cold War History, Vol. 16, No. 2 (2016), pp. 195212, doi.org/10.1080/14682745.2015.1129607; and David Holloway, "The Soviet Union and the Creation of the International Atomic Energy Agency," Cold War History, Vol. 16, No. 2 (2016), p. 187, doi.org/10.1080/14682745.2015.1124265.

47. Coding India's nuclear program is notoriously difficult. Because New Delhi claimed to have carried out a peaceful nuclear explosion, some authors, including Philip Bleek, do not categorize India as a nuclear weapons state starting in 1974. Primary sources, however, indicate that Indian leaders understood that peaceful nuclear explosives and nuclear weapons were essentially the same. Minutes of a Special Meeting of the AECI in the Room of the Prime Minister Jawaharlal Nehru, New Delhi, January 16, 1950, carton F86, Relations avec l'Inde, fond Frédéric Joliot-Curie, Bibliothèque Nationale de France, Paris, France (henceforth BNF). 
ons, as these imported technologies boost a country's ability to pursue its nuclear ambitions.

India took its first major step toward creating a civilian nuclear program in 1948, when Prime Minister Jawaharlal Nehru ordered the establishment of the Atomic Energy Commission of India (AECI). From the outset, Homi Bhabha, the chairman of AECI and the father of India's nuclear program, sought to capitalize on the emerging nuclear market. ${ }^{48}$ India was well positioned to exploit the competitiveness of the market, because it had access to suppliers in the capitalist and the communist camps. Fearing that other suppliers, especially France, which India regarded as a potential supplier of a research reactor, would dominate the Indian market, the United States treated New Delhi as an exception to its hard-nosed policy of not exporting nuclear knowledge, materials, and technology ${ }^{49}$ The U.S. Atomic Energy Commission and the AECI signed an agreement in 1948 for the release of information that would benefit Indian nuclear research centers. ${ }^{50}$ In 1951, New Delhi announced that it planned to build a small nuclear reactor for research and isotope production. ${ }^{51}$ The following year, the AECI started looking into acquiring a medium-sized research reactor. ${ }^{52}$

India's interest in nuclear energy made suppliers hopeful that business opportunities would abound, irrespective of U.S. efforts to stop the nuclear market in its early stages. ${ }^{53}$ As a result, nuclear trade negotiations with New Delhi-and other potential buyers-intensified. Confronted with the suppliers' doggedness, U.S. policymakers thought that their best chance of influencing the market and preventing proliferation was to sell nuclear technology to interested buyers. Thus, in 1954, the Eisenhower administration amended the Atomic Energy Act of 1946 and announced the Atoms for Peace program. India was among the first countries to sign a nuclear cooperation agreement with the United States in 1955. The conclusion of the agreement did not mean that India would axiomatically obtain U.S. nuclear technology. Negotiations around technology transfers continued.

To maximize its leverage vis-à-vis suppliers, India indicated it was pre-

48. Homi J. Bhabha, Note on the Organization of Atomic Energy in India, April 26, 1948, IDSAHBP-26041948, Homi Bhaba Papers, Institute for Defence Studies and Analyses, Tata Institute of Fundamental Research, Mumbai, India.

49. Letter from M.N. Saha to Joliot Curie, July 3, 1949, carton F86, fond Frederic Joliot-Curie, BNF; and Minutes of a Special Meeting of the AECI in the Room of the Prime Minister Jawaharlal Nehru, New Delhi, January 16, 1950.

50. “U.S. Nuclear Information to Aid Indian Research," Nucleonics, Vol. 2, No. 1 (January 1948), p. 76.

51. "India Plans Reactor for Experimental Purposes," Nucleonics, Vol. 8, No. 5 (May 1951), p. 84.

52. "World Progress in Atomic Energy," Nucleonics, Vol. 10, No. 12 (December 1952), p. 7.

53. Howard Gary, "Foreign Market for Package Nuclear Power," Nucleonics, Vol. 11, No. 5 (May 1953), pp. 14-15; and “In Brief," Nucleonics, Vol. 11, No. 11 (November 1953), p. 100. 
pared to consider offers for nuclear assistance from any country, provided no political strings were attached. ${ }^{54}$ The fear that New Delhi might turn to the Soviet Union was especially important for spurring Washington into action. ${ }^{55}$

In 1954, the United States partnered with Canada to sell India the CIRUS reactor. $^{56}$ The Americans offered 10 tons of heavy water, which, U.S. analysts acknowledged, India might have bought elsewhere "were it not for [its] early need." 57 For Washington, the CIRUS deal, finalized in 1956, represented an opening into the Indian nuclear power market. The difficulty of winning contracts to export nuclear technology to India, however, increased as growing numbers of suppliers expressed interest in doing business with New Delhi.

India played this situation to its advantage. Bhabha cleverly decided to accept an invitation from the Soviet Union to visit Moscow in July 1955, just as the United States was arranging to set up another research reactor near Bombay. U.S. analysts expected Bhabha's trip to result in an offer of nuclear assistance from the Soviet Union. ${ }^{58}$ The Indians kept the Americans in suspense, neither confirming nor denying whether they had reached an agreement with Moscow. In fact, they invited Nikita Khrushchev, the first secretary of the Communist Party, and Premier Nikolai Bulganin to India in November 1955, after which Moscow proposed a nuclear cooperation arrangement. ${ }^{59}$ Indian officials then put pressure on the Americans by volunteering information about the many perks the Soviet Union could provide. ${ }^{60}$ If the Americans wanted to win the contract, they had to match or surpass Moscow's offer.

As Moscow's sales offensive was unfolding, the United States was becoming increasingly invested in the development of nuclear energy in India. ${ }^{61}$ Seizing a larger share of the Indian nuclear imports would not only help the United States dominate the global nuclear market, but stem proliferation as well. ${ }^{62}$

54. “Roundup: Foreign Developments," Nucleonics, Vol. 13, No. 8 (August 1955), p. 9.

55. Jayita Sarkar, "'Wean Them Away from French Tutelage': Franco-Indian Nuclear Relations and Anglo-American Anxieties during the Early Cold War, 1948-1952," Cold War History, Vol. 15, No. 3 (2015), p. 392, doi.org/10.1080/14682745.2014.989840.

56. According to Canadian records, the CIRUS sale was concluded under an aid commitment to India, known as the Colombo Plan. Memorandum from Warren, Deputy Minister to Jean-Luc Pepin, Minister of Trade and Commerce, November 12, 1968, RG 20, Vol. 1644, 20-68-Ra Pt. 3, Library and Archives of Canada, Ottawa, Canada (henceforth LAC).

57. "Roundup: Bilateral Agreements," Nucleonics, Vol. 13, No. 3 (March 1955), p. 8.

58. "Roundup: Reactor News," Nucleonics, Vol. 13, No. 10 (October 1955), p. 12.

59. Anthony Cuomo, Memorandum of a Conversation, Department of State, Washington, D.C., June 17, 1959, Foreign Relations of the United States (FRUS) 1958-1960, Vol. 25: South and Southeast Asia (Washington, D.C.: U.S. Government Printing Office [GPO], 1992), p. 501.

60. Ibid.

61. Anthony Cuomo, Memorandum of a Conversation, Department of State, June 15, 1959, FRUS 1958-1960: Vol. 25: South and Southeast Asia (Washington, D.C.: GPO, 1992), pp. 498-499.

62. Douglas C. Dillon, Telegram from the Department of State to the Embassy in India, Washington, D.C., May 15, 1959, FRUS 1958-1960: Vol. 25: South and Southeast Asia (Washington, D.C.: GPO, 1992), p. 492. 
Both Moscow and Washington wanted to sell nuclear technology to India, because each was afraid the other might not do enough to prevent New Delhi from developing a nuclear weapons capability. ${ }^{63}$

New Delhi's manipulation of nuclear suppliers paid off handsomely: U.S. firms built India's first nuclear power stations and played a key role in helping it set up its first plutonium reprocessing plant. ${ }^{64}$ Furthermore, the Indians secured a better financial package from Washington than they would have received from Moscow, and they also got better technology and better terms of use. Thanks largely to U.S.-supplied nuclear technology, especially the reprocessing plant, India produced plutonium for the first time in $1964 .{ }^{65}$

India proved even more adept at manipulating suppliers that were on the same side in the Cold War. Although Britain, Canada, and France were all members of the North Atlantic Treaty Organization, they competed vigorously with one another to export nuclear technology. Taking notice of this rivalry, the Indians put feelers out to all three. Paris responded positively and promptly. ${ }^{66}$ French nuclear exports policy was not governed by the 1946 Atomic Energy Act, which greatly restricted the ability of Britain and Canada to disseminate nuclear information to foreign countries. ${ }^{67}$ After offering to help India exploit its rich natural resources (especially its monazite ores) and signing a nuclear cooperation agreement in 1951, the French Atomic Energy Commission proposed building a beryllium-moderated reactor for India. ${ }^{68}$

India made sure to provide enough information about these negotiations to

63. Roger Hilsman, Research Memorandum for Dean Rusk, August 8, 1962, folder “India: Nuclear (Tarapur), 1961-1963," box 422, Robert W. Komer, National Security Files, John F. Kennedy Presidential Library, Boston, Massachusetts (henceforth JFKPL).

64. On U.S.-supplied nuclear power plants, see U.S.-Indian Agreement for Cooperation Signed, August 8, 1963, folder "India: Nuclear (Tarapur), 1961-1963," box 422, Robert W. Komer, National Security Files, JFKPL. On the transfer of reprocessing technology from the United States, Roberta Wohlstetter notes that an "American firm, Vitro International, was responsible for variations in the design of the Indian facility [at Trombay], a transfer of technology which apparently required no license on the part of the American government." Wohlstetter, "The Buddha Smiles': AbsentMinded Peaceful Aid and the Indian Bomb," Monograph No. 3, in Albert Wohlstetter et al., eds., Can We Make Nuclear Power Compatible with Limiting the Spread of Nuclear Weapons? (Los Angeles, Calif.: Energy Research and Development Administration, May 1977), p. 61; and George Perkovich, India's Nuclear Bomb: The Impact on Global Proliferation (Berkeley: University of California Press, 1999), pp. 28, 55.

65. Perkovich, India's Nuclear Bomb, p. 28; and Central Intelligence Agency (CIA), "Scientific Intelligence Report: Indian Nuclear Energy Program," November 6, 1964, National Security Archive, George Washington University, Washington, D.C. (henceforth NSA), https://nsarchive2.gwu.edu/ NSAEBB/NSAEBB187/IN06.pdf.

66. Letter from M.N. Saha to Joliot Curie, July 3, 1949; and Minutes of a Special Meeting of the AECI in the Room of the Prime Minister Jawaharlal Nehru, New Delhi, January 16, 1950.

67. Sarkar, "'Wean Them Away from French Tutelage,'” p. 379.

68. Ibid., p. 386; H.S. Isbin, "Nuclear Reactor Catalog," Nucleonics, Vol. 10, No. 3 (March 1952), p. 11; and Note from the Department of Atomic Affairs to the General Secretary, January 2, 1968, 127QO/379, Culture et Relations Culturelles, Archives du Ministère des Affaires Étrangères, La Courneuve, France (henceforth MAE). 
the other Western suppliers to keep them interested and push them to offer a better deal. New Delhi indicated that "two other foreign governments are expected to cooperate" on this project, without specifying which ones. ${ }^{69}$ Such open-ended statements piqued the interest of the British, who feared that Britain was "running a bad third to the French and the Americans."70 In 1955, Britain transferred the designs for India's first research reactorAPSARA—a light-water, medium-enriched uranium reactor. ${ }^{71}$

India's deal with Britain provided more advantages for New Delhi than its 1951 agreement with France. With the latter deal, France and India would first undertake studies regarding the construction of a research reactor and then build the actual facility under the authority of the French Atomic Energy Commission, all over a period of five years. ${ }^{72}$ Britain gave the Indian government more control over the nuclear technology it received, and the APSARA reactor design outclassed the natural uranium design offered by France. ${ }^{73}$ As Bhabha admitted, "Enriched uranium was an improvement over natural uranium." 74 Moreover, APSARA provided the foundation for India's nuclear infrastructure. Thus, by manipulating suppliers, New Delhi secured a better product, at a better price, and under better terms.

The prospect of India acquiring the bomb with the help of transfers from foreign suppliers unsettled U.S. policymakers. ${ }^{75}$ Yet, the intense security competition between the United States and the Soviet Union weakened their ability to thwart India's nuclear ambitions. They did manage to create the IAEA, but it could do little by itself to curb proliferation, and indeed it had little sway over India, which saw its safeguards as a case of the haves keeping the have-nots down. ${ }^{76}$ New Delhi refused to place the facilities it imported under international safeguards, preferring instead bilateral arrangements with its suppliers. ${ }^{77}$ These deals helped undermine the thwarters' efforts to corral nuclear

69. Isbin, "Nuclear Reactor Catalog," p. 11.

70. Secret letter from Roger Makins at the UK Foreign Office to M.W. Perrin at the Ministry of Supply, June 5, 1951, AB16/565, Technical cooperation with India, 1947-54, National Archives of the United Kingdom, Kew, U.K. (henceforth UKNA), cited in Sarkar, "'Wean Them Away from French Tutelage,'" p. 386.

71. Perkovich, India's Nuclear Bomb, p. 27.

72. Sarkar, "'Wean Them Away from French Tutelage,'” p. 387.

73. CIA, "Scientific Intelligence Report: Indian Nuclear Energy Program," March 26, 1958, NSA, https://nsarchive2.gwu.edu/NSAEBB/NSAEBB187/IN01.pdf.

74. Anthony Cuomo, Memorandum of a Conversation, Department of State, Washington, D.C., June 17, 1959, p. 500.

75. Survey of Indian Nuclear Energy Program, September 6, 1961, folder "India: Nuclear (Tarapur), 1961-1963," box 422, Robert W. Komer, National Security Files, JFKPL.

76. Roehrlich, "The Cold War, the Developing World, and the Creation of the International Atomic Energy Agency (IAEA), 1953-1957," pp. 207, 209.

77. On the bilateral safeguards agreement between Canada and India, see Duane Bratt, The Politics of CANDU Exports (Toronto: University of Toronto Press, 2006), p. 95; and Annexure to Political Report for the month of June 1974, HI/1012/75/74, box 227, Political Reports from the Indian Embassy in Canada, National Archives of India, New Delhi, India, p. 2. 
vendors into a cartel that could enforce strict nonproliferation standards against buyers such as India.

By the time relations between the superpowers had begun to improve in the late 1960s, it had become clear that their efforts to stop proliferation had failed. The Nuclear Nonproliferation Treaty (NPT), which was signed in July 1968 and ratified in March 1970, was an effort by Moscow and Washington to deal with this problem. ${ }^{78}$ The NPT signatories offered a "grand bargain": non-NWS would receive assistance for their civilian nuclear programs from nuclear suppliers in exchange for promising to forswear the bomb. ${ }^{79}$ Compliance with the "peaceful uses" clause would be the responsibility of the IAEA. To buttress the NPT, in 1970, the United States, joined shortly thereafter by the Soviet Union, corralled the most important suppliers in the informal Zangger Committee. ${ }^{80}$ Its task was to determine which technologies were most likely to facilitate the spread of nuclear weapons. India, together with other key states, however, refused to sign or ratify the NPT, insulating themselves from the pressures the superpowers sought to apply through the web of institutions underpinning the emerging nonproliferation regime.

Nuclear technology transfers eventually allowed India to become a proliferator. The technology itself did not compel India to seek nuclear weapons. Rather, it was mainly security concerns stemming from China's 1964 nuclear test that motivated India to develop a nuclear option and, in May 1974, conduct a nuclear test. ${ }^{81}$ The transfers, however, gave India the technological capability to become a hedger and then a nuclear weapons state. For example, the heavy water reactor from Canada, coupled with the U.S.-origin reprocessing technology, proved essential for producing the plutonium used in the 1974 test. India was able to purchase these and other facilities in the early Cold War, because the superpowers' hostility toward each other prevented them from forming a cartel that could regulate the nuclear market. Thus, India was free to employ a supplier manipulation strategy to great effect, as my theory predicts.

\section{THE CREATION OF THE CARTEL}

India's nuclear explosion in 1974 sent a powerful message to the world: countries could use the market to become proliferators, despite the nonproliferation

\footnotetext{
78. Andrew J. Coe and Jane Vaynman, “Collusion and the Nuclear Nonproliferation Regime," Journal of Politics, Vol. 77, No. 4 (October 2015), pp. 983-997, doi.org/10.1086/682080.

79. The "grand bargain" theory is discussed in Andreas Wenger and Liviu Horovitz, "Nuclear Technology and Political Power in the Making of the Nuclear Order," in Roland Popp, Liviu Horovitz, and Andreas Wenger, eds., Negotiating the Nuclear Non-Proliferation Treaty: Origins of the Nuclear Order (London: Routledge, 2017), p. 223.

80. Isabelle Anstey, "Negotiating Nuclear Control: The Zangger Committee and the Nuclear Suppliers' Group in the 1970s," International History Review, Vol. 40, No. 5 (2018), pp. 975-995, doi.org/ 10.1080/07075332.2018.1449764.

81. Perkovich, India's Nuclear Bomb, p. 3; and Narang, “Strategies of Nuclear Proliferation," p. 136.
} 
strategy employed by the superpowers and despite the NPT. By the mid1970s, conditions seemed ripe for a major wave of proliferation. Competition among suppliers had greatly intensified, with new vendors such as China, Italy, Pakistan, South Africa, and West Germany having joined the market. Commercial nuclear negotiations now regularly crossed ideological lines. In the Eastern bloc, Czechoslovakia, Romania, and Yugoslavia sought nuclear assistance from Britain, Canada, France, the Soviet Union, and the United States. Moscow was negotiating to supply nuclear power plants to Finland, Japan, and North Korea, and highly enriched uranium to West Germany. Brazil was trying to develop the full nuclear fuel cycle with help from France, Israel, Japan, the United States, and West Germany, while France hoped to sell ENR technology to Iran, Pakistan, and South Korea.

In response, the thwarters created the NSG in 1975 to prevent countries from purchasing sensitive nuclear technologies. The NSG began as an informal forum for consultations among suppliers, but quickly evolved into a comprehensive exports control coordination mechanism. ${ }^{82}$ The United States, the Soviet Union, and Britain moved swiftly to enact the cartel's agenda. Others, including France and West Germany, opposed joining the NSG, but eventually agreed after receiving pressure from Washington and Moscow, giving the cartel a critical mass of suppliers.

In January 1976, the NSG adopted governing guidelines designed to curb competition among its members and to ensure that nuclear transfers could not be diverted to military uses. ${ }^{83}$ The thwarters demanded that NSG members refrain from selling ENR facilities to countries that did not have them. If such a sale took place, it was subjected to intrusive inspections by the IAEA. The reactor market remained more competitive, but these technologies could not produce fissile material by themselves, and they were also subject to safeguards. Consequently, no aspiring NWS or hedgers that emerged in the later Cold War acquired the bomb. The thwarters' efforts to curb proliferation benefited from the aggregate pressure applied on suppliers by the IAEA and the NPT, as well as the NSG. This trio of institutions worked together, but the NSG was the key instrument in the nonproliferation battle. For the remainder of the Cold War, the superpowers continued their cooperation on nonproliferation. As Mark Hibbs notes: "Over the years, the number of NSG member states increased, but from the outset the group's core membership included two geostrategic

82. William Burr, "A Scheme of 'Control': The United States and the Origins of the Nuclear Suppliers' Group, 1974-1976," International History Review, Vol. 36, No. 2 (2014), pp. 252-253, 269, doi.org/10.1080/07075332.2013.864690.

83. James Cameron and Or Rabinowitz, "Eight Lost Years? Nixon, Ford, Kissinger and the NonProliferation Regime, 1969-1977," Journal of Strategic Studies, Vol. 40, No. 6 (October 2017), p. 854, doi.org/10.1080/01402390.2015.1101682. 
adversaries: the Soviet Union and the United States. Regardless of their global rivalry, the two superpowers throughout the Cold War cooperated without interruption in administering the NSG and the nuclear trade regime. The effectiveness of the group was never threatened by East-West political strife; the U.S. and the Soviet Union proved to be like-minded on most issues concerning preventing nuclear nonproliferation including threats that emerged as a consequence of exports of nuclear material, equipment, and technology." ${ }^{84}$

\section{SOUTH KOREA: BOXED IN BY THE NUCLEAR SUPPLIERS' GROUP}

My theory predicts that South Korea should have been well positioned in the early Cold War to acquire nuclear transfers through a highly competitive suppliers' market. By the late Cold War, however, doing so would have become extremely difficult, given the growing role of the NSG, the IAEA, and the NPT in curbing proliferation.

Seoul initiated a peaceful nuclear program in the early 1950s, as part of its efforts to rebuild the country after the Korean War. Plans for using nuclear energy for postwar reconstruction started surfacing in January $1954 .{ }^{85}$ Foreign suppliers moved in to help South Korea begin building a nuclear industry. Seoul secured a nuclear research reactor from the United States through the Atoms for Peace program. ${ }^{86}$ Britain, France, and West Germany helped train South Korea's nuclear scientists, but the program got off to a slow start, mainly because the task of recovering from the Korean War was so daunting and resources were scarce. ${ }^{87}$

That situation began to change in the early 1960s, when the South Korean Atomic Energy Promotion Committee-a governmental body chaired by the prime minister, in charge of reviewing and approving national policy related to the use of nuclear energy-announced that it would hold a competitive bid for nuclear power plants. Belgium, Britain, Canada, France, and the United States all offered to sell nuclear power plants to South Korea. ${ }^{88}$ After a few false starts, the South Koreans narrowed down the search to British and U.S. companies. ${ }^{89}$

All the companies offered Seoul attractive financial packages and terms of

84. Mark Hibbs, "A More Geopoliticized Nuclear Suppliers Group?" Strategic Trade Review, Vol. 3, No. 5 (Autumn 2017), p. 6.

85. “Atomic Matter for Peaceful Use," Times, January 7, 1954, p. 6.

86. "Roundup: Foreign News," Nucleonics, Vol. 13, No. 8 (August 1955), p. 12; and Seongho Sheen, "Nuclear Sovereignty versus Nuclear Security: Renewing the ROK-U.S. Atomic Energy Agreement," Korean Journal of Defense Analysis, Vol. 23, No. 2 (June 2011), p. 274.

87. Se Young Jang, "The Development of South Korea's Nuclear Industry in a Resource- and Capital-Scarce Environment," in Gareth Austin, ed., Economic Development and Environmental History in the Anthropocene: Perspectives on Asia and Africa (London: Bloomsbury, 2017), p. 249.

88. Tom Whitney, "The Race for Electric Power through Atoms," Korea Times, January 25, 1956. 89. Jungmin Kang and H.A. Feiveson, "South Korea's Shifting and Controversial Interest in Spent 
use. ${ }^{90}$ London's bid was more appealing, because Britain could supply natural uranium reactors, which would have eased Seoul's dependence on U.S. enriched uranium and, if necessary, provided more leeway for South Korea to pursue a nuclear weapons program. The Export-Import Bank and other financial institutions, coupled with political pressure from Washington, however, helped the United States win the competition. ${ }^{91}$

South Korea became an aspiring hedger in 1969, mainly as a result of a turn in U.S. foreign policy. The Richard Nixon administration, which took office in January 1969 in the midst of the Vietnam War, decided not only to slowly disengage from Vietnam, but also to reduce the United States' military presence around the world. The aim of the "Nixon Doctrine" was to push U.S. allies, including South Korea, to do much more to provide for their own security. ${ }^{92}$ The new doctrine caused great alarm in Seoul, prompting President Park Chung-hee to seek at least a breakout capability, and nuclear weapons if necessary. ${ }^{93}$

To become a hedger, South Korea launched an impressive effort to acquire heavy-water reactors and a plutonium reprocessing facility, which were better suited for facilitating proliferation than the U.S.-supplied reactors. Seoul approached Canada for the reactors and France for the reprocessing technology. ${ }^{94}$ Unfortunately for South Korea, the thwarters had already begun work to create the NSG, which would prevent Seoul from acquiring any transfers that would facilitate its pursuit of a nuclear option. ${ }^{95}$ Secretary of State Henry Kissinger, for instance, worried that "exporters, in their competitive zeal to make a sale, would fail to insist on the appropriate safeguards" on nuclear facilities transferred to South Korea. ${ }^{96}$ As another high-level U.S. policymaker

Fuel Reprocessing," Nonproliferation Review, Vol. 8, No. 1 (Spring 2001), p. 71, doi.org/10.1080/ 10736700108436839.

90. Choi and Hwang, "Effects of Nuclear Technology Export Competition on Nuclear Nonproliferation," p. 350.

91. "NPG Sees Credit Threat to Big Nuclear Plant Order," Times, May 5, 1969, p. 19; Hugh de Wet, "U.S. Pressure over S. Korea Reactor Alleged," Times, May 2, 1969, p. 25; and "South Korea Approves \$150m: A-Plant Financing," Financial Times, October 24, 1970, p. 12.

92. Memorandum of Conversation between President Nixon and President Park, August 21, 1969, NSC Files, box 1023, Presidential/HAK MemCons, Richard M. Nixon Presidential Library, Yorba Linda, California.

93. Se Young Jang, "The Evolution of U.S. Extended Deterrence and South Korea's Nuclear Ambitions," Journal of Strategic Studies, Vol. 39, No. 4 (June 2016), p. 502, doi.org/10.1080/01402390 .2016.1168012.

94. Bratt, The Politics of CANDU Exports, pp. 114-116; and David Rush, Telegram from U.S. Embassy in Paris to SecState Washington, November 29, 1974, Central Foreign Policy Files (CFPF), Record Group (RG) 59, Access to Archival Databases, NARA (henceforth AAD NARA).

95. W. Richard Smyser, David D. Elliott, U.S. National Security Memorandum: Development of U.S. Policy toward South Korean Development of Nuclear Weapons, February 28, 1975, Korea, box 9, National Security Adviser Presidential Country Files for East Asia and the Pacific, Gerald R. Ford Presidential Library, Ann Arbor, Michigan (henceforth GFPL).

96. U.S. National Security Council Memorandum: ROK Weapons Plans, March 3, 1975, Korea (4), box 9, National Security Adviser Presidential Country Files for East Asia and the Pacific, GFPL; 
said at the time, "There is no need to pussyfoot" on this matter. He continued, "The Koreans are serious tough customers, bent in this case on a potentially harmful cause. A direct, early, and firm approach will be most appropriate and will have best chance of success." 97

The Gerald Ford administration, however, believed that curtailing sensitive transfers to Seoul without offering anything in return might be unsuccessful. To lure South Korea away from France, the United States suggested the creation of a multinational reprocessing center. ${ }^{98}$ The South Koreans, hoping that Washington's proposal would provide them with the opportunity to play suppliers off against each other, initially showed enthusiasm for the proposal. ${ }^{99}$ Realizing that its offer played to Seoul's advantage, the United States refocused its attention on suppliers. The Americans, by "pounding their fist on the table," secured a commitment from France that it would withdraw its offer to sell a reprocessing plant to South Korea provided it was compensated. ${ }^{100}$

The United States also won over Canada, which threatened to deny South Korea access to its CANDU reactors if Seoul did not cancel its reprocessing deal with France. ${ }^{101}$ In addition, Washington informed South Korea that if it did not abandon its plans to close the nuclear fuel cycle, the United States would withhold funding for the nuclear reactors it had already sold the South Koreans and would end all nuclear-related commerce as well. ${ }^{102}$ Facing pressure on all fronts, Seoul started showing signs of backing down in January $1976 .{ }^{103}$

and Henry Kissinger, Circular Telegram from SecState Washington to U.S. Embassies in London, Bonn, Tokyo, Paris, Ottawa, Moscow, June 19, 1975, CFPF, RG 59, AAD NARA.

97. U.S. Department of State Cable: ROK Plans to Develop Nuclear Weapons and Missiles, March 12, 1975, box 11, Korea State Department Telegrams, to SecState NODIS (4), National Security Adviser Presidential Country Files for East Asia and the Pacific, GFPL.

98. Shinsuke Tomotsugu, "After the Hegemony of the 'Atoms for Peace' Programme: Multilateral Non-Proliferation Policy under the Nixon and Ford Administrations," in John Baylis and Yoko Iwama, eds., Joining the Non-Proliferation Treaty: Deterrence, Non-Proliferation, and the American Alliance (New York: Routledge, 2019), p. 53.

99. Richard Sneider, Telegram from U.S. Embassy in Seoul to SecState Washington, September 10, 1975, CPFP, RG 59, AAD NARA.

100. David Rush, Telegram from U.S. Embassy Paris to SecState Washington, October 30, 1975, CFPF, RG 59, AAD NARA; and Memorandum from Jan Lodal and David Elliott of the National Security Council Staff to Secretary of State Kissinger, Washington, July 24, 1975, FRUS 1969-1976: Vol. E-14: Documents on Arms Control and Nonproliferation, 1973-1976 (Washington, D.C.: GPO, 2015), p. 523.

101. Joseph Sisco, Telegram from SecState Washington to USDel, January 21, 1976, CFPF, RG 59, AAD NARA; and Se Young Jang, "Bringing Seoul into the Nonproliferation Regime: The Effect of ROK-Canada Reactor Deals on Korea's Ratification of the NPT," Nuclear Proliferation International History Project Working Paper No. 9 (Washington, D.C.: Woodrow Wilson International Center for Scholars, 2017), pp. 17-28.

102. Henry Kissinger, Circular Telegram from SecState Washington to U.S. Embassies in Seoul and Ottawa, June 6, 1975, CFPF, RG 59, AAD NARA.

103. Henry Kissinger, Telegram from SecState Washington to Joint Chiefs of Staff, SecDef, CIA, White House, January 26, 1976, CFPF, RG 59, AAD NARA. 
Washington's success in thwarting Seoul's efforts to acquire a reprocessing facility was a major setback for South Korea's nuclear ambitions. Before the deal with France was canceled in 1976, U.S. intelligence analysts had estimated that Seoul would be able to obtain a nuclear weapon within the next ten years. ${ }^{104}$ Once the Canadian and French deals were stopped, this would no longer be possible. Still, the United States did not completely halt South Korea's nuclear pursuits. With U.S. assistance, Seoul constructed the unsafeguarded Laboratory for Quantum Optics at the Korea Atomic Energy Research Institute, where scientists carried out uranium enrichment experiments. ${ }^{105}$ South Korean scientists soon realized that they could not produce enough fissile material for a bomb in that facility. Lacking alternatives, Chun Doo-hwan, who became president in 1980, decided by 1981 to terminate South Korea's efforts to become a hedger and to focus instead on the peaceful uses of nuclear energy. Thus, the South Korean case demonstrates how thwarters can work together to create a cartel that can regulate the market and curtail supplier competition in ways that curb proliferation.

\section{THE CARTEL PUTS PRESSURE ON THE MARKET}

With the end of the Cold War, the United States became the unipole and the only remaining thwarter in the system. Therefore, when coalition forces discovered in 1991 Iraq's clandestine nuclear weapons program, which had been helped by foreign assistance during the Cold War, Washington chose to take decisive action to strengthen the NSG. With pressure from the United States, members agreed to ban the sale of ENR facilities, apply full-scope safeguards on new nuclear transfers, and broaden the NSG control list. ${ }^{106}$

U.S. demands that NSG members refrain from transferring ENR technology quashed commercial competition in this sector of the nuclear market. Since 1991, the few ENR exports that passed NSG muster have been "overt and legal and have been made to states that already possess E[N]R capabilities." 107 This contraction in nuclear trade left aspiring NWS and aspiring hedgers deprived

104. U.S. Department of State Cable: ROK Plans to Develop Nuclear Weapons and Missiles, March 12, 1975.

105. Fuhrmann and Tkach, "Almost Nuclear: Introducing the Nuclear Latency Dataset"; see Republic of Korea Country Coding Sheet in ibid.

106. Tadeusz Strulak, "The Nuclear Suppliers Group," Nonproliferation Review, Vol. 1, No. 1 (Fall 1993), p. 4. This list contains dual-use items and technologies such as "equipment, materials, software, and related technology that could make a major contribution to a 'nuclear explosive activity,' an 'unsafeguarded nuclear fuel-cycle activity,' or acts of nuclear terrorism." IAEA, "Communication Received from the Permanent Mission of the Republic of Korea to the International Atomic Energy Agency regarding Certain Member States' Guidelines for Transfers of NuclearRelated Dual-Use Equipment, Materials, Software and Related Technology" (Vienna, Austria: IAEA, November 8, 2016).

107. Fred McGoldrick, "Limiting Transfers of Enrichment and Reprocessing Technology: Issues, Constraints, Options" (Cambridge, Mass.: Project on Managing the Atom, Belfer Center for Sci- 
of the technology necessary to acquire the bomb or to become a hedger, which explains why the nuclear club did not expand in the post-Cold War period.

Washington also sought to bring suppliers outside the NSG into it. The strategy succeeded with Argentina, Brazil, China, and South Africa, but was unsuccessful with India, Iran, Israel, Libya, North Korea, and Pakistan, all of which were capable of selling ENR technology. Still, these vendors could not freely transfer sensitive nuclear technologies, because any buyer that traded with them would immediately come under fire from the United States and the cartel's other members. Indeed, NSG members stigmatized any transactions involving these suppliers as "black market" deals. The most these outsiders could hope for was to supply each other. North Korea and Iran, for example, obtained Pakistani enrichment technology, enabling them to become a nuclear weapons state and a hedger, respectively. ${ }^{108}$

North Korea and Iran are the exceptions, however. Few buyers have dared to deal with non-NSG suppliers. In effect, those two cases indicate how effective the NSG has been, as the only way those countries could acquire sensitive nuclear technology was to deal with a supplier outside the cartel. They also show that as long as a country has access to an alternative source of sensitive nuclear transfers, sanctions, sabotage, and the threat of military attack are unlikely to prevent it from becoming a proliferator.

\section{ROMANIA: THE RISE AND FALL OF A NUCLEAR HEDGER}

My theory predicts that, in the post-Cold War period, aspiring NWS or hedgers will have even more difficulty than in earlier periods purchasing sensitive nuclear technology, especially ENR, because cartels are strongest in unipolarity. Such countries are therefore likely to abandon their nuclear ambitions. Romania, which was an aspiring hedger, provides a test case of this prediction.

Romania started building a peaceful nuclear program in the mid-1950s, when the Soviet Union, responding to the United States' Atoms for Peace program, loosened its restrictions on nuclear cooperation. Among other technologies the Romanians received was a Soviet-type research reactor, which they

ence and International Affairs, John F. Kennedy School of Government, Harvard University, May 2011), p. 9.

108. Pakistani policymakers have blamed the transfer of centrifuges to Iran and North Korea on "rogue," nonstate actors such as the A.Q. Khan network. The Pakistani government's interest in exporting gas centrifuges has made experts skeptical about these claims. Leonard S. Spector, Nuclear Ambitions: The Spread of Nuclear Weapons, 1989-1990 (Boulder, Colo.: Westview, 1990), p. 212; Wyn Q. Bowen and Joanna Kidd, "The Iranian Nuclear Challenge," International Affairs, Vol. 8, No. 2 (March 2004), p. 262, doi.org/10.1111/j.1468-2346.2004.00382.x; and Sharon A. Squassoni, "Weapons of Mass Destruction: Trade between North Korea and Pakistan" (Washington, D.C.: Congressional Research Service, Library of Congress, 2003), pp. 12-13. 
used for training purposes. ${ }^{109}$ Bucharest also requested nuclear power reactors, but the Soviet leadership proved hesitant, preferring instead to channel its nuclear assistance to Czechoslovakia, East Germany, and Poland. The Central European satellites represented the industrial core of the Eastern bloc, with a higher chance to successfully develop nuclear power programs.

Rebuffed by Moscow, Bucharest turned to Western suppliers and chose to adopt an incremental approach. To obtain a nuclear power reactor, Romania first sought to purchase a research reactor. It accomplished this goal by playing the British off against the French. ${ }^{110}$ In April 1966, Bucharest signed an agreement with Britain for the sale of a subcritical reactor, known as HELEN, which could be used for nuclear research. ${ }^{111}$

By 1967, Romania had plans to procure the technologies necessary for an extensive nuclear program: nuclear power plants, breeder reactors, and a reprocessing facility. ${ }^{112}$ Bucharest's intentions were not entirely peaceful. For example, Romania's prime minister told Soviet leaders in March 1967 that his country's greatest impediment to developing a nuclear weapons program was a lack of technological capabilities. He stated, "Romania does not have in mind to build nuclear weapons because it cannot do so. If it could, it probably would."113 A month later, Nicolae Ceauşescu, the general secretary of Romania's Communist Party, told the leader of Israel's Communist Party: "We thought about cooperating with Israel to build an atomic weapon together." 114 The decision by Romania to secure the capabilities that would have enabled it to weaponize in a short period of time, instead of launching a program exclusively dedicated to acquiring nuclear weapons, qualify it for aspiring hedger status.

The Soviet Union, which had become increasingly worried about proliferation after China's October 1964 nuclear test, tried to impede Ceauşescu's

109. Eliza Gheorghe, “Atomic Maverick: Romania's Negotiations for Nuclear Technology, 19641970," Cold War History, Vol. 13, No. 3 (2013), p. 375, doi.org/10.1080/14682745.2013.776542. 110. Minutes from Smith to Brown, and Mason, February 19, 1964, FO 371/176255, UKNA. 111. J.A. Birch, Letter from the British Embassy in Bucharest, April 21, 1966, FO 625/13, UKNA. 112. Meeting of the Executive Committee of the RCP, October 31, 1967, 147/1967, Cancelarie, Comitetul Central al Partidului Comunist Român (CC PCR), Arhivele Naţionale Istorice Centrale, Bucharest, Romania (henceforth ANIC), pp. 35-40. In 1970, the Romanians set their sights on acquiring a pilot reprocessing plant with a capacity of 40 tons per year. Setting-up a Nuclear Technology Institute in Romania, Note from Emilian Rodean to Nicolae Ecobescu, December 29, 1970, 241/12.A.39/1970-1971, Arhivele Ministerului Afacerilor Externe, Bucharest, Romania (henceforth AMAE), pp. 30, 36.

113. Minutes of the Meeting between the Romanian Communist Party Delegation, Led by Nicolae Ceauşescu, Ion Gheorghe Maurer, Paul Niculescu-Mizil, and the Soviet Communist Party Delegation, Led by Leonid Brezhnev, Alexei Kosygin, Yuri Andropov, Andrei Gromyko, March 17-18, 1967, 14/1967, Relaţii Externe, CC PCR, ANIC, p. 66.

114. Minutes of Conversation between Nicolae Ceauşescu and Shmuel Mikunis, April 12, 1967, 25/1967, Relaţii Externe, CC PCR, ANIC, p. 8. 
nuclear aspirations by exporting a nuclear power plant to Romania. In December 1967, it offered to sell a light-water reactor, provided Bucharest agreed to import Soviet highly enriched uranium and return the spent fuel to the Soviet Union. ${ }^{115}$ This arrangement would have given the Kremlin significant control over Romania's nuclear program and curtailed Bucharest's plans to become a hedger. Moscow's efforts failed, however, because Bucharest was able to employ a strategy of supplier manipulation from 1964 to 1978.

In addition to playing Britain and France off against each other in the mid1960s, Romania negotiated for nuclear power plants with Canada, Italy, Sweden, the United States, and West Germany. ${ }^{116}$ In their eagerness to expand market share, these suppliers bent over backward to entice Bucharest with their products, prices, and terms of use. In the late 1960s, the Canadians put together such an appealing package that the director general of Atomic Energy Canada Ltd. (AECL) exclaimed: "Are we that desperate?!"117 The Canadian government and its nuclear industry's effort to defeat "the formidable international competition" paid off. ${ }^{118}$ AECL won the contract and signed an agreement with Bucharest for the provision of five CANDU power reactors, which produce more plutonium than light-water reactors. By the time the deal was sealed in 1976, Ceauşescu had become more open about his hedging strategy. ${ }^{119}$ On several occasions, he called into question the utility of the NPT as a brake on nuclear proliferation. ${ }^{120}$ Moreover, he reassured the Canadians that if

115. Minutes of the Meeting between Nicolae Ceauşescu and Leonid Brezhnev, December 15, 1967, 101/1967, Relaţii Externe, CC PCR, ANIC, pp. 62-63.

116. Vol. 1644, 20-68-Ra Pt. 1-3, RG 20, LAC; Roumanie, Série 29, Sous-série 17, dossier 8/1, MAE; Busta 15, Fasc. A 98, 129-137, Documenti del Consigliere Diplomatico del Presidente del Consiglio, Archivio Centrale dello Stato, Rome Italy; and Business Relations between the FRG and Romania, Delivery of a Nuclear Power Plant to Romania, 1969-1970, B 63, 416, 84.00, Politisches Archiv des Auswärtigen Amtes, Berlin, Germany (henceforth PAAA).

117. Memorandum from Gauthier to Kniewasser, October 10, 1968, Vol. 1644, 20-68-Ra Pt. 3, RG 20, LAC.

118. Ibid.

119. According to a U.S. diplomatic cable, in September 1974 , less than half a year after the Indian peaceful nuclear explosion, the Romanian Communist Party program stated that "no state need refrain from A-weapons acquisition if nuclear powers refuse to significantly reduce weapons stocks." Robert Ingersoll, Telegram from SecState to the U.S. Embassy in Ottawa, February 3, 1976, CFPF, RG 59, AAD NARA.

120. Prior to signing the NPT in 1968, Romania strongly opposed the treaty, because, as Ion Gheorghe Maurer told the Soviet leadership, the treaty would tie Romania's hands. Minutes of the Meeting between the Romanian Communist Party Delegation, Led by Nicolae Ceauşescu, Ion Gheorghe Maurer, Paul Niculescu-Mizil, and the Soviet Communist Party Delegation, Led by Leonid Brezhnev, Alexei Kosygin, Yuri Andropov, Andrei Gromyko, March 17-18, 1967, p. 66. In September 1975, Nicolae Ceauşescu explained Bucharest's views of the NPT: "Romania has greatly praised the Nuclear Nonproliferation Treaty, but this treaty did not solve anything, and internally, we disapproved of it, but for political interests we thought that with or without us, the treaty would have been signed anyway; we had not yet decided to produce nuclear weapons and so we thought to ourselves: when we have the capability to produce them, with or without the treaty, if we decide to produce them, we will produce them. In politics you cannot always applaud 
Bucharest ever tried to build a nuclear weapon, "we certainly won't do it together with Canada, we will do it alone." ${ }^{121}$

France and the United States also provided technology that was crucial for Ceauşescu's plan to keep Romania's nuclear option open. In 1974, Bucharest acquired a dual-core research reactor from the Gulf Corporation by pitting the Americans against the French, among other suppliers. ${ }^{122}$ Romania also sought to acquire shielded nuclear radiation containment chambers, commonly referred to as "hot cells," which are used in the chemical recovery of plutonium from spent fuel. To pressure Washington, Bucharest put feelers out to Britain, France, Sweden, and West Germany. ${ }^{123}$ U.S. fears that Romania might "acquire necessary know-how and material over a reasonably short span of years from Western suppliers such as Germans, British, or French, or even Chinese," caused U.S.-Romanian hot cell negotiations to intensify in 1976 to the point where the two sides began talking about contracts. ${ }^{124}$

Determined to breathe new life into the French nuclear industry, France quickly made a counteroffer. Tensions between Paris and Washington over nuclear issues were simmering at this point, however, mainly because the United States was determined to employ the newly formed NSG to prevent proliferation. In August 1976, the Ford administration pressured France to abandon its plans to sell reprocessing plants to South Korea and Pakistan. ${ }^{125}$ French President Valéry Giscard d'Estaing feared that the NSG would threaten France's status as a first-rank nuclear energy state and compromise its relations with clients. The U.S.-French spat made it clear to the Romanians that Washington was serious about preventing proliferation, but it also opened the

what you like." Minutes of Conversation between Nicolae Ceauşescu and Abdel Mohsen Abu Meyzer, September 25, 1975, 174/1975, Relaţii Externe, CC PCR, ANIC, p. 28.

121. Minutes of conversation between Nicolae Ceauşescu and John S. Foster and A.M. Aikin, June 26, 1976, 79/1976, Relatii Externe, CC PCR, ANIC, p. 10.

122. Author phone interview with Robert H. Chesworth, former managing director of General Atomics, March 15, 2013; and Summary of the Joint Memo regarding the Import of a Materials Testing Research Reactor and Hot Cells, November 2, 1972, 10/1972, Economică, CC PCR, ANIC, p. 183.

123. German-Romanian Negotiations for the Construction of a Nuclear Power Plant in Romania, Telegrams, July-August, 1975, B 63, 117672, 410.26 RUM, PAAA; and Telegram from the Romanian Embassy in London to the Minister of the Machine-Building Industry, Ion Avram, August 18, 1976, 528/1976, Correspondence regarding the Collaboration between Romania and the United Kingdom, AMAE.

124. Robert Ingersoll, Telegram from SecState to the U.S. Embassy in Ottawa, February 3, 1976; and Henry Kissinger, Telegram from SecState to the U.S. Embassy in Bucharest, U.S.-Romanian Nuclear Cooperation: Hot Cell End-Use Statement, August 25, 1976, CFPF, RG 59, AAD NARA. 125. Pierre Lellouche, "Giscard's Legacy: French Nuclear Policy and Non-Proliferation, 1974-81," in Robert Boardman and James F. Keeley, eds., Nuclear Exports and World Politics (New York: St. Martin's, 1983), p. 33; and Memorandum to the Secretary of State from ACDA Director Fred Iklé and Policy Planning Staff Director Winston Lord, "Analytical Staff Meeting on Non-Proliferation Strategy," July 31, 1974, in William Burr, ed., National Security Archive Electronic Briefing Book, No. 467, NSA, https://nsarchive2.gwu.edu/nukevault/ebb467/. 
possibility that France could be manipulated into making a deal and offer excellent financial terms and weak safeguards.

When Jimmy Carter became president in 1976, Romania realized its window of opportunity was rapidly closing. ${ }^{126}$ Playing the United States off against France would no longer work, because Carter was deeply committed to strengthening the NSG and curtailing ENR transfers. Romania ended its negotiations with the U.S. firm General Atomics and struck a deal in 1978 for the supply of hot cells from Ateliers et Chantiers de Bretagne, which offered a much better price and less intrusive inspections than the United States. ${ }^{127}$

Romania stopped procuring nuclear technology from the West after buying the reprocessing technology from France. ${ }^{128}$ The increasing levels of strict compliance required by the Carter administration and the United States' Western partners, operating through the NSG, presented Bucharest with a serious threat of outside interference. Above all, Romanian leaders feared full-scope safeguards, which would be applied to both imported and indigenous nuclear facilities and materials. ${ }^{129}$ Determined to move forward, Ceauşescu ordered Romanian scientists in 1983 to use the hot cells to extract plutonium from spent fuel. ${ }^{130}$ This procedure, which was realized two years later, represented a small step toward Romania becoming a hedger.

The Cold War ended, and Ceauşescu was overthrown in late 1989. ${ }^{131}$ Soon thereafter, Romania decided to focus on building a civilian nuclear program. With the arrival of unipolarity, which allowed the United States to strengthen

126. Note from Romulus Neagu to Foreign Minister George Macovescu, May 7, 1977, 3883/1977, AMAE, pp. 40-41.

127. Telegram from the Secretary of State Cyrus Vance to the U.S. Embassy in Ottawa, February 28, 1977, AAD NARA; Telegram from the U.S. Embassy in Bucharest to the Secretary of State Cyrus Vance, June 14, 1977, AAD NARA; author interview with Lucian Biro, former president of the National Commission for Nuclear Activities Control, Bucharest, Romania, February 8, 2013; author interview with Serban Valeca, former deputy director of the Romanian Authority for Nuclear Activities, Bucharest, Romania, February 18, 2013; and author phone interview with Chesworth.

128. Note to Ilie Verdet Virgil Cazacu, Stefan Andrei from the Chancellery of the Central Committee, June 24, 1979, 49/1979, Cancelarie, CC PCR, ANIC, p. 214.

129. Nuclear powers, including the Soviet Union, had placed great emphasis on this provision, since the days of the NPT negotiations. Roland Timerbaev, The Nuclear Suppliers Group: Why and How It Was Created, 1974-1978 (Moscow: Center for Policy Studies in Russia, 2000), pp. 49-51. Romania resisted attempts to let inspectors check all of its nuclear activities. Telegram from the Romanian Permanent Mission to the IAEA and UNIDO to the CSEN Vice-President Emilian Rodean, June 6, 1973, 5196/1973, Inspections, Matters concerning the Application of Safeguards Agreements, AMAE, pp. 17-19.

130. Note from the CC RCP Chancellery to D. Dǎscǎlescu, Ştefan Andrei, and Florin Dumitrescu, June 6, 1983, 327/1983, Economică, CC PCR, ANIC, pp. 10-21; and Petre T. Frangopol, "Mihai Bălănescu," in Revista de Politica Știinţei şi Scientometrie, Vol. 1, No. 4 (December 2012), p. 358.

131. Shortly before being overthrown, Ceauşescu claimed that Romania had the wherewithal to produce nuclear weapons. Alison Smale, "President Says Romania Has Nuclear Weapons Potential," Associated Press, April 15, 1989; and "Hungarian Diplomat: Romania Making Military Threats," Associated Press, July 11, 1989. 
the NSG and exert enormous pressure on suppliers, it was virtually impossible for Romania to get nuclear materials and technology from foreign suppliers. Moreover, it could not compensate for that loss by relying on indigenous sources. In the early 1990s, for example, Bucharest had only two operational research reactors, both of which used highly enriched uranium supplied by the United States and Russia. Romania could not get fresh fuel for them, however, because it had decided in the mid-1980s not to allow IAEA inspectors to implement the safeguards agreements it had signed with the superpowers. Another option was to produce plutonium from spent natural uranium fuel. Romania could not pursue this route either, because the nuclear power plants from Canada were not yet finished. Furthermore, expanding the hot cell laboratory into an industrial-scale reprocessing plant required foreign assistance, which the Romanians could not secure. As Nucleonics Week noted in 1996, more than 80 percent of the sources of supply "scheduled to contribute to the ambitious [Romanian] nuclear program are now out of the nuclear business." 132

The Romanian case supports my theory regarding aspiring hedgers and the nuclear market. Bucharest was able to acquire nuclear transfers in the early Cold War by exploiting the competition in the nuclear market. But with the creation of the NSG in the late Cold War, it became almost impossible for Romania to acquire the necessary ENR technology to become a hedger. That cartel became even stronger in the post-Cold War years, which allowed the United States to push Romania off its proliferation course altogether. Bucharest's reversal is an illustration of the dynamics that contributed to the plateauing of proliferation in the post-Cold War era: with an ever shrinking pool of candidates achieving NWS status, membership in the nuclear club remained largely constant.

\section{SUMMARY}

The India, South Korea, and Romania case studies shed light on how changes at the systemic level involving thwarters shape market dynamics and affect the prospects for proliferation. India, which received substantial transfers in the early Cold War, when security rivalry between the superpowers was intense, was able to weaponize. South Korea, which began seriously seeking nuclear transfers in the late Cold War, when the rivalry between the thwarters had abated, saw its proliferation plans dashed with the creation of the NSG. Romania, which was adept at manipulating suppliers in the early Cold War, found itself in a situation similar to South Korea's once the NSG was in place and it was cut off from the transfers it needed to become a hedger.

132. Mark Hibbs, "Romania Hopes to Save Remains of \$10-Billion Know-How Investment," Nucleonics Week, July 18, 1996, p. 6. 


\section{The Future of Proliferation}

The international system is moving from unipolarity toward multipolarity. ${ }^{133}$ U.S. preponderance is increasingly being contested by a rising China and a resurgent Russia. My theory predicts that the thwarters will be unable to coordinate with one another to maintain an effective cartel, which will limit their ability to check the competition among suppliers, especially regarding ENR transfers. The result is likely to be a sharp uptick in proliferation.

Indeed, by early 2019, the growing security rivalry among China, Russia, and the United States already appeared to be weakening the NSG. As one expert notes, negotiations within the suppliers' group "have become increasingly beset with strategic considerations of member states." ${ }^{134}$ For instance, the three thwarters could not agree on how to expand the cartel's membership to include two "pariah" suppliers, India and Pakistan. The United States and Russia support India joining the NSG, which began considering the matter in 2011. ${ }^{135}$ China, however, favors admitting Pakistan, but not India. A compromise among the thwarters seemed possible in the early years of the negotiations, but Beijing's opposition to admitting India has hardened in recent years. The prospects for getting India and Pakistan to comply with the rules and regulations put in place by the thwarters look dim. This lack of consensus not only perpetuates existing gaps and weaknesses in the global export controls framework, but is a harbinger of the paralysis that is likely to overwhelm the cartel if the security rivalry among the thwarters intensifies.

Moreover, the waning of the thwarters' effectiveness could lead to renewed competition among suppliers. The 2018 announcement of Saudi Arabia's ambitious nuclear plans provides a useful example. Riyadh attempted to launch a nuclear program in the mid-1970s, but its plans did not materialize as nuclear transfers became more difficult to access after the NSG was created. Saudi Arabia's fortunes, however, have begun to change, as the international system has begun to move from unipolarity to multipolarity. In 2015, it secured a research reactor from Argentina by exploiting supplier competition. This transfer represents a mere stepping-stone on the path to the full nuclear fuel cycle.

More importantly, Riyadh desires nuclear power plants and enrichment technology, which it is trying to obtain by pitting suppliers against one another, as my theory would predict. Saudi Arabia has the luxury of choice: not

133. The National Security Strategy of the United States of America (Washington, D.C.: Office of the President, December 2017).

134. Hibbs, "A More Geopoliticized Nuclear Suppliers Group?" p. 13. See also Ariel E. Levite and Toby Dalton, "Leveling Up the Nuclear Trade Playing Field" (Washington, D.C.: Carnegie Endowment for International Peace, September 7, 2017).

135. Hibbs, "A More Geopoliticized Nuclear Suppliers Group?" 
only does it have access to legitimate suppliers, such as France and South Korea, but it has also ingratiated itself with vendors outside the cartel, such as Pakistan, whose nuclear weapons program Riyadh allegedly helped fund. ${ }^{136}$ The prospect of other sellers sealing a deal with Saudi Arabia has nudged China, Russia, and the United States to step in and submit their own bids. ${ }^{137}$

The United States and Russia have had some success in their attempts to curb proliferation by imposing their own technology on buyers. In unipolarity, the United States established the "gold standard" of nuclear cooperation agreements - a framework that requires recipients of U.S. nuclear technology to forfeit their right to enrich or reprocess. ${ }^{138}$ In 2010, Russia implemented a "build-own-operate" business model-an approach that involves Russian control throughout the entire lifespan of a nuclear facility: construction, fueling, waste disposal, and decommissioning. ${ }^{139}$ These developments send a powerful signal to all suppliers, including those outside the NSG cartel, not to bother competing to sell ENR technology to countries bound by agreements with the United States and Russia because of the risk of thwarter interference.

China, however, has yet to indicate whether it will require similar agreements regarding its nuclear exports. Instead, Beijing has been undermining one of the key rules set by the NSG-that its members should not sell nuclear technology to nonsignatories of the NPT-through its nuclear technology transfers to Pakistan. ${ }^{140}$ As a great power on the rise, China seeks to reap all the financial and commercial benefits the global nuclear market can offer. ${ }^{141}$ It will not purposefully help other states acquire nuclear weapons. Yet, if its unwillingness to adopt more stringent nuclear exports policies persists, the existing cracks in the nonproliferation edifice are likely to widen. These divergences can play to Saudi Arabia's advantage. If the United States or Russia offer to sell reactors and enrichment technology to the Saudis, but also impose

136. On Saudi Arabia's negotiations with France and South Korea, see Makio Yamada, “GCC-East Asia Relations in the Fields of Nuclear and Renewable Energy: Opportunities and Barriers" (Oxford: Oxford Institute for Energy Studies, September 2016), p. 15. On Saudi-Pakistani nuclear cooperation, see Sarah Burkhard et al., Saudi Arabia's Nuclear Ambitions and Proliferation Risks (Washington, D.C.: Institute for Science and International Security, March 30, 2017).

137. Michael R. Gordon, Timothy Puko, and Summer Said, “U.S. Pursues Saudi Nuclear Deal, despite Proliferation Risk," Wall Street Journal, February 20, 2018, https://www.wsj.com/articles/ saudi-resistance-to-nuclear-standards-could-roil-u-s-reactor-deal-1519122600.

138. Lauren Carty, "Pride and Pragmatism: The UAE's Nuclear Strategy," Bulletin of the Atomic Scientists, June 2, 2014, https://thebulletin.org/2014/06/pride-and-pragmatism-the-uaes-nuclearstrategy/.

139. Alissa de Carbonnel, "Russian Nuclear Ambition Powers Building at Home and Abroad," Reuters, July 22, 2013, https://www.reuters.com/article/russia-nuclear-rosatom/russian-nuclearambition-powers-building-at-home-and-abroad-idUSL5N0F90YK20130722.

140. Jost Wübbeke and Guan Ting, "China's Nuclear Industry Goes Global," Diplomat, February 11, 2016, https://thediplomat.com/2016/02/chinas-nuclear-industry-goes-global/.

141. Tong Zhao, "The 'New Normal' for China's Economy and Great Power Diplomacy," China Policy Review, (Beijing: Carnegie-Tsinghua Center for Global Policy, March 1, 2015). 
strict nonproliferation provisions, Riyadh can turn to China, which can offer more lenient terms. ${ }^{142}$ In that event, the United States and Russia are also likely to cut corners and hesitate to demand Riyadh to subscribe to the "gold standard" or to a build-own-operate arrangement. Getting China to embrace a stricter nuclear exports policy would help shrink Saudi Arabia's room for maneuver, but that may be difficult to achieve in a world where the great powers are engaged in intense security rivalry.

Limiting Riyadh's access to nuclear wherewithal must be accompanied by efforts to address the reasons Saudi Arabia might aspire to be a hedger. On this front, recent U.S. actions give few reasons for optimism. The leadership in Riyadh has conditioned its nuclear restraint on what Iran does with its nuclear program. The Saudi crown prince, Mohammad bin Salman, has warned that "without a doubt if Iran developed a nuclear bomb, we will follow suit as soon as possible." 143 Moreover, Saudi Arabia has made it clear that it will not renounce its prerogative to enrich or reprocess, mainly because Iran has retained that right, not to mention the capacity to do so through the Joint Comprehensive Plan of Action. ${ }^{144}$ Indeed, Riyadh's plans to acquire an enrichment capability follow directly from its determination to match Iran's capabilities and become a hedger. ${ }^{145}$

The United States' withdrawal from the Joint Comprehensive Plan of Action, together with its plans to ramp up economic sanctions on Tehran and possibly even resort to military force, have prompted Iran to prepare for the resumption of uranium enrichment on a large scale. Should that happen, it will give further impetus to Riyadh's efforts to acquire ENR technology. Other countries in the region may follow suit. In 2015, after the Iran nuclear deal was completed, the United Arab Emirates announced that it no longer felt bound to the "gold standard" and that it now had the right to enrich and reprocess. Turkey, which has signed a build-own-operate contract with Rosatom, may reconsider the terms of its deal with Russia. At some point, Iraq and Egypt may be tempted to resume their nuclear weapons programs. In these circumstances, the ideal situation would be for the thwarters to employ a strong NSG to prevent Saudi Arabia from playing suppliers against each other to acquire

142. Nicholas L. Miller and Tristan A. Volpe, “Geostrategic Nuclear Exports: The Competition for Influence in Saudi Arabia," War on the Rocks blog, February 7, 2018, https://warontherocks.com/ 2018/02/geostrategic-nuclear-exports-competition-influence-saudi-arabia/.

143. "Saudi Crown Prince: If Iran Develops Nuclear Bomb, So Will We," CBS News, March 15, 2018, https://www.cbsnews.com/news/saudi-crown-prince-mohammed-bin-salman-iran-nuclearbomb-saudi-arabia/.

144. Mark Hibbs, “How Saudi Arabia Can Go Nuclear (but Prevent Proliferation)," National Interest, February 4, 2018, https://nationalinterest.org/feature/how-saudi-arabia-can-go-nuclearprevent-proliferation-24345.

145. Burkhard et al., Saudi Arabia's Nuclear Ambitions and Proliferation Risks. 
the technology necessary to become a hedger. Such an outcome, however, is unlikely in multipolarity, where the NSG cartel will be undermined from within by internal conflicts and from without by non-NSG suppliers.

\section{Conclusion}

This article has sought to determine why the number of nuclear weapons states has not grown significantly since the mid-1970s, when the world seemed ripe for proliferation. The key to solving this puzzle is to look at what has happened in the nuclear market over time, especially regarding the interactions among suppliers, buyers, and thwarters. I have argued that the more fiercely suppliers compete with one another, the easier it is for recipient countries to secure the materials and technologies necessary to join the nuclear club. The great powers, which are the thwarters in the system, can curb proliferation by creating a cartel that regulates how suppliers compete with one another and what they can sell. How successful they are ultimately depends on the global distribution of power-whether it is unipolar, bipolar, or multipolar-and the intensity of the security rivalry among the great powers.

A close examination of the nuclear age supports my argument. Most NWS (seven out of ten) emerged during the early Cold War, when the system was bipolar and the security rivalry between the Soviet Union and the United States was intense. During that period, nuclear exporters vied with each other to increase their respective shares of the market, which allowed proliferators to play suppliers off against one another to obtain nuclear assistance. This process was facilitated by the inability of the superpowers to establish a cartel. The intensity of the superpowers' rivalry began to diminish in the late 1960s and reached the point by 1975 where they could cooperate to create the NSG, which put significant limits on the sale of ENR, thus markedly slowing down proliferation. Only two countries became nuclear weapons states in the late Cold War. With the end of the bipolar competition and the coming of unipolarity, proliferation leveled off with nine nuclear weapons states in 1991 and in 2014, when the unipolar moment began to wane.

Shifts in the global distribution of power, such as the current transition from unipolarity to multipolarity, are difficult to reverse or steer. In these circumstances, is there anything that thwarters can do to mitigate the proliferation problem? The great powers do have some agency. They should avoid pursuing foolish policies that make a bad situation worse. The Donald Trump administration's decision to withdraw the United States from the Joint Comprehensive Plan is an example of a wrongheaded decision. Not only will this move make it more difficult to prevent Iran from acquiring nuclear weapons, but also it 
will make further proliferation in the Middle East more likely, as other countries will be inclined to imitate Iran.

Security competition among the great powers will invariably lead to more disputes such as the present ones over the South China Sea, Syria, and Ukraine. It behooves Beijing, Moscow, and Washington, however, to recognize that waging those conflicts will have serious costs for the proliferation front, where they have a shared interest in thwarting the spread of the bomb. Given the destruction wrought by nuclear weapons, countering proliferation should not be forsaken for other foreign policy goals. Indeed, the great powers should work assiduously to manage their security rivalries in ways that do the least damage to the cartel, which is the key to preventing the nuclear club from expanding.

Finally, this article suggests several avenues for future research. First, there are a variety of questions concerning the relationship between buyers and suppliers. Buyer manipulation-in contrast to my focus on supplier manipulation-may be a frequently used strategy, with its own set of advantages and drawbacks. Moreover, buyers may be able to play off against one another only a relatively small number of suppliers. Perhaps when a buyer casts too wide a net, it fails to muster the resources to sustain itself for a long period of time. Diversifying the sources of supply may be a double-edged sword. Also, in the future, researchers may seek to examine how the supplier-buyer ratio has evolved since the dawn of the nuclear age. Another issue concerns the differences among suppliers. For example, emerging suppliers may be more desperate to sell than traditional suppliers. Or, certain countries that have the capability to become suppliers may decide not to do so. Investigating the rationale for restraint could explain why some nuclear deals are successful whereas others fail. Studying these matters would provide analysts with a more fine-grained picture of the nuclear market, which is not only important for better understanding proliferation, but for preventing it as well. 